\title{
Lessons From Fiascos in Russian Corporate Governance
}

\author{
By: Merritt B. Fox and Michael A. Heller
}

Working Paper Number 282

October 1999 


\section{LESSONS FROM FIASCOS IN RUSSIAN CORPORATE GOVERNANCE}

Merritt B. Fox and Michael A. Heller

The University of Michigan Law School

Ann Arbor, MI 48109-1215

734-763-5878 and 734-763-4855

merrittf@umich.edu and mheller@umich.edu

October 25, 1999

Preliminary Draft

(C) Merritt B. Fox and Michael A. Heller, 1999 


\title{
LESSONS FROM FIASCOS \\ IN RUSSIAN CORPORATE GOVERNANCE \\ Merritt B. Fox and Michael A. Heller
}

Contact info: merrittf@umich.edu or mheller@umich.edu

Version: October 25, 1999

\begin{abstract}
"Bad corporate governance" is often invoked to explain poor enterprise performance, but the catch phrase is never precisely defined neither its consequences for the real economy, nor its causes in particular countries has been adequately explained. This paper uses Russian enterprise examples to address these open questions in corporate governance theory. We define corporate governance by looking to the economic functions of the firm rather than to any particular set of national corporate laws. Firms exhibit good corporate governance when their managers maximize residuals and, in the case of investor-owned firms, make pro rata distributions to shareholders. First, using this definition, we develop a typology that shows the channels through which bad corporate governance can inflict damage on the real economy. The topology helps identify vulnerabilities to corporate governance problems that may appear in any country and it suggests a new way to tailor policy responses. Second, we explain the causes of poor corporate performance in Russia by looking to the particular conditions prevailing at privatization - untenable initial firm boundaries and insider allocation of firm shares - and the bargaining dynamics that followed. The focus on initial conditions helps expand a comparative corporate governance literature built on United States, Western European, and Japanese models. Lessons from Russian fiascos counsel caution as to "stakeholder" proposals - including labor or local communities in formal corporate governance - and generate testable hypotheses regarding potential losses from the multiple large block share ownerships typical of many U.S. firms, especially close corporations.
\end{abstract}




\section{LESSONS FROM FIASCOS \\ IN RUSSIAN CORPORATE GOVERNANCE \\ Merritt B. Fox and Michael A. Heller}

\section{TABLE OF CONTENTS}

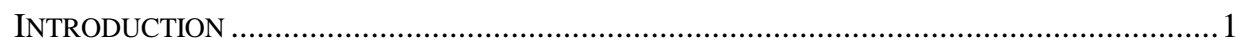

I. CORPORATE GOVERnANCE FAILURES IN RUSSIA.....................................................

A. A Simple Definition ........................................................................................ 3

B. The Failure to Maximize Residuals...................................................................6 6

Pathology 1: Continued Operation of Value-Destroying Firms. ..................... 7

Pathology 2: Failure to Use Existing Capacity Efficiently ............................12

Pathology 3: Mis-Investment of Internally Generated Cash Flow .................. 13

Pathology 4: Failure to Implement Positive Net Present Value Projects........ 14

Pathology 5: Failure to Identify Positive Net Present Value Projects ............ 17

C. The Failure to Make Pro-Rata Distributions..................................................... 18

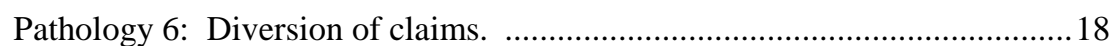

Pathology 7: Diversion of assets ................................................................ 21

D. A Simple Framework Meets Complex Failures .............................................22

II. The Role of InITIAL Conditions IN RuSSIAN PRIVATIZATION .............................25

A. Initial Conditions in Russia .......................................................................26

1. Untenable Firm Boundaries..............................................................26

2. Dominance by Insider Groups .............................................................29

B. How Initial Conditions Cause Corporate Governance Failures ........................36

1. Peculiar Firm Boundaries and the Failure to Maximize Residuals ...............36

2. Insider Dominance and the Failure to Maximize Residuals .......................37

3. Insider Dominance and Non Pro-Rata Distributions ................................45

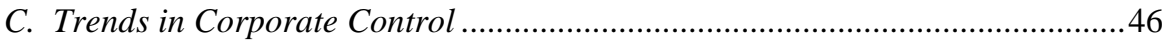

1. Dynamics of Initial Ownership Patterns. ................................................46

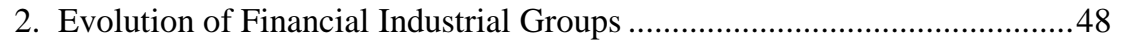

3. Some Reform "Thought Experiments" .............................................50

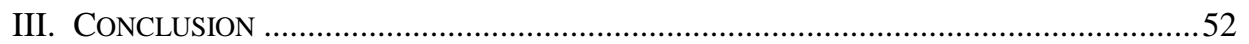




\section{LESSONS FROM FIASCOS IN RUSSIAN CORPORATE GOVERNANCE Merritt B. Fox and Michael A. Heller ${ }^{*}$}

\section{INTRODUCTION}

Russian industry has performed poorly since privatization. The voluminous literature on transition economies explains this poor performance primarily in terms of continued bureaucratic meddling, poor macro-economic and tax policy, and low human capital. Problems in corporate governance are often mentioned as well, ${ }^{1}$ but little analyzed. The goal of this paper is to open the black box of "poor corporate governance" by detailing its consequences for the Russian economy and by tracing its causes to the initial structure of Russian privatization. Understanding what went wrong in Russia teaches lessons not only for transition policy, but also for corporate governance theory generally.

After the fall of Russian communism, state enterprises were rapidly privatized, stock markets created, and a corporate legal code adopted. However, even at its peak before the 1998 collapse, the total stock market capitalization of all Russian industry only reached about $\$ 130$ billion - less than Intel Corp. ${ }^{2}$ In early 1999 the numbers were

Professors of Law, The University of Michigan. Thanks to workshop participants at the University of Michigan Law School and the American Law and Economics Association Annual Meeting. Thanks to Sean Grimsley, David Guenther, Mary Mitchell, and Chris Serkin for able research assistance. The Cook Endowment provided generous research support.

For example, as one veteran commentator on Russian privatization notes: "The fundamental issue is ... not primarily macroeconomic. All along, Russia has suffered from serious problems in corporate governance." Anders Aslund, A Crisis of Confidence, MOSCOW TIMES, June 3, 1998; see also OECD ECONOMIC SURVEYS: RUSSIAN FEDERATION, 1997-1998, at 129-35 (listing "barriers to restructuring and investment: corporate governance, capital markets, the tax system, and regional protectionism").

2 Gary Peach, An Outstanding Year Despite Market Narrowness, Moscow TiMES, Jan. 13, 1998, available in Nexis Library, Curnws File. This peak represented an eleven-fold improvement over 1994, when total stock market capitalization, based on voucher auctions prices, was under $\$ 12$ billion. M. BOYCKO, A. SHLEIFER \& R. VISHNY, PRIVATIZING RUSSIA 117 (1995). By the summer of 1998, "the Moscow Times index of 50 leading shares hit an all-time bottom, lower than its starting level four years ago.” Katy Daigle, Bill Improves Shareholder Rights in Russia, Moscow TIMES, July 14, 1998. See, e.g., Patricia Kranz, Fall of an Oligarch, BusINESS WeEK, Mar. 1, 1999, 
"phenomenally abysmal; if they could sink any further, shares would literally have a value of zero. As it is, the entire market is made up of penny stock."3 These numbers represent a trivial fraction of the apparent value of the underlying corporate assets controlled by Russian corporations. $^{4}$ The low prices reflect severe corporate governance problems, including the high probability that the firms' underlying assets will be grossly mismanaged and that whatever cash flow is produced will be diverted to benefit insiders or reinvested in unproductive projects. In this paper, we focus on two questions: What are the consequences of these corporate governance problems for the real economy in Russia? Why are these problems so widespread and persistent?

To answer the first question, we define corporate governance in a way that looks to the economic functions of the firm rather than to any particular set of national corporate laws. Firms exhibit good corporate governance when they both maximize residuals and, in the case of investor owned firms, make pro rata distributions to shareholders. Bad corporate governance is just the failure by a firm to meet one or both of the above conditions. Whether managers operate their firms in ways that meet these ideals depends on the structure of constraints and incentives in which they operate, a structure that depends in part, but only in part, on the prevailing legal system. In this paper, we give more precision to the idea of "bad" corporate governance by developing a typology of the kinds of damage to the real economy that loosely constrained, poorly incentivized managers can inflict. We identify, with examples, why this damage has been particularly severe in Russia.

As for the second question, we go beyond standard causal explanations of poor corporate governance, which include the low level of corporate transparency, lack of effective adjudication of corporate law violations, weak enforcement of judgments, and the absence of a network of trust among Russian businessmen, factors that are common to all postsocialist corporate economies. We expand this inquiry by focusing on

at 44 ("From its peak in October, 1997, the market capitalization of [ ] three big industrial holdings - Sidanko Oil, Svyazinvest Telecommunications, and Norilsk Nickel - has dropped from about $\$ 31$ billion to $\$ 3.8$ billion.”).

3 Gary Peach, Poor Management Destroys Sberbank, Tatneft, MGTS, Moscow TIMES, Dec. 15, 1998.

4 Put another way, as measured by stock prices, a barrel of proven oil reserves owned by a Russian oil company was worth about one twentieth of a similar barrel owned by a Western oil company counterpart. BOYCKO, SHLEIFER \& VISHNY, supra note *, at 120; Das Kapital Revisited, THE ECONOMIST, Apr. 8, 1995, at 15 ("[A] barrel of oil in the ground owned by a Russian company is worth 10 cents. A barrel owned by a western company is worth $\$ 5.50$."). 
the role of initial conditions - specifically, the initial boundaries of privatized firms and the initial allocation of firm shares to insiders - and the bargaining dynamics that have followed. Our focus helps explain why Russian corporate performance remains so much worse than in other transition countries.

Our analysis is not confined to the Russian experience alone, rather it provokes rethinking of corporate governance theory more generally. Though our typology emerges from study of Russian corporate fiascos, it has larger applicability - linking corporate governance failures to real economy effects in a more comprehensive way than we have found in the existing literature. We provide an analytic tool that helps identify vulnerabilities to particular corporate governance problems in any economy and points toward more tailored policy responses. Our work on initial conditions also has more general applicability. The existing scholarly literature on comparative corporate governance reflects the range of firm boundaries and dominant shareownership patterns in the United States, Western Europe and Japan. The Russian experience falls, at least initially, outside this range and hence suggests useful lessons about the roles that firm boundaries and ownership structure may play in corporate governance theory, lessons that may benefit Russia, other countries in transition, and even the United States.

Part I defines bad corporate governance and, using Russian examples, develops a typology of its consequences for the real economy. Part II describes the initial conditions of Russian privatization and shows how they continue to cause corporate governance failures. Part III concludes.

\section{CORPORATE Governance FAILURES IN Russia}

\section{A. A Simple Definition}

Everyone in the transition economy debate talks about the importance of "good corporate governance," but no one quite specifies what it means. What little commentary does exist tends to focus on some idealized set of corporate law rules. ${ }^{5}$ In contrast, we measure the quality of corporate governance in terms of the social welfare impact of firm decision-making. We make no prejudgments about which institutional arrangements would work best in any particular country.

\footnotetext{
${ }^{5}$ See, for example, the OECD Principles of Corporate Governance (1999).
} 
Under our definition, good corporate governance requires two things: managers must maximize their firm's residuals and firms, at least investor owned firms, must distribute those residuals on a pro-rata basis to shareholders. Let us consider each element in turn.

The first key feature of a well-governed firm is that its managers make decisions that seek to maximize the residuals that the firm generates over time, discounted to present value. Residuals are defined as the difference between what a firm pays at contractually predetermined prices to obtain its inputs and what it receives for its output. We define this criteria in terms of residual maximization rather than share value maximization because we do not want to foreclose the possibility that labor or consumer owned firms would not be optimal in certain situations. ${ }^{6}$ In an ordinary investor-owned corporation, however, the residuals go to shareholders who provide the firm's equity-based capital, which is the only input not obtained at contractually predetermined prices. Thus, for such a firm, maximizing share value is equivalent to maximizing its residuals. ${ }^{7}$

The conclusion that it is socially desirable for a firm to maximize its residuals flows from the assumption, which is standard in simple models of the corporation, that the firm purchases its inputs and sells its outputs in competitive markets and there are no important externalities or subsidies. Thus, the contractually pre-determined prices the firm pays for its inputs (other than its equity-based capital) are equal to the value of what the firm takes from society; similarly, the firm's selling prices for its output equals the value of what it gives to society. Maximizing the difference in value between inputs and outputs maximizes the firm's contribution to society and hence constitutes efficient behavior. ${ }^{8}$

In the case of an ordinary investor-owned firm, the second feature

6 See generally HENRY HANSMANN, THE OWNERSHIP OF ENTERPRISE (1996).

7 Oliver Williamson, Corporate Governance, 93 YALE L. J. 1197 (1984) (discussing problems created by multiple classes of residual claimants).

We make the standard assumptions that the firm purchases its inputs and sells its outputs in competitive markets and that there are no important externalities or subsidies not because we believe they are consistently true in Russia or any other country clearly they are not. We make these assumptions because they allow us to focus on the social welfare effects of things that go on within the firm in reaction to the constraints imposed directly by the legal system and by the firm's markets for inputs, outputs and capital. Such a focus allows us to separate out more precisely the different problems in the Russian economy. Thus these assumptions allow for more precise policy analysis. Their standard nature also makes it easier to draw larger corporate governance lessons from the Russian experience since most analyses of corporate governance problems in other countries make the same assumptions. 
of good governance is that the residuals are in fact distributed to shareholders and in a pro-rata fashion. Meeting this second condition is not strictly necessary for one period, static efficiency. For a single period, all that is necessary is that the residuals be maximized, whoever then receives them. The pro-rata distribution condition is helpful, however, in achieving the efficient allocation of resources over time because pro-rata distribution greatly increases the ability of firms to raise capital by issuing new equity.

For a firm to raise capital by selling equity at a price worthwhile to its owners, a firm needs credibly to promise to abide by both principles of good corporate governance - that the firm will strive to maximize its future residuals and shareholders will receive some determinable proportion of these residuals as dividends or other distributions. The expectation of receiving such distributions is what makes holding a share worthwhile as a financial instrument and what induces outsiders to provide cash in return for shares. A firm can make itself credible in several ways: by developing a record of abiding by its promises, by being subject to a binding legal system, and by structuring incentives so managers gain if they fulfill their promises and suffer otherwise. If a firm acts contrary to its promises, it undermines its own record and becomes less able to acquire new equity financing. Note, also, that when a legal system fails to punish such a firm, an individual firm's decision to break its promises imposes externalities: investors become generally less willing to buy equity of other firms governed by the same legal system, in other words weak corporate governance in existing firms poisons the well for new firms which hope to use equity markets.

Defective corporate governance means that a firm does not meet one or both elements of our definition. Most attention in reports on transition economies has focused on problems relating to non pro-rata distributions: for example, when insiders dilute shares of outsiders, loot companies, fail to pay dividends, and engage in many other tactics that deprive outside shareholders of their pro-rata share of the wealth generated by the firm. ${ }^{9}$ Non pro-rata distributions do indeed help explain low stock prices and the poor performance of the corporate sector. But

9 The mix corporate governance problems may be difficult to tease apart. For example, one commentator notes, "problems range from murder to bad market trends, but all boil down to basic corporate governance: Directors and their cohorts appear to have milked or outright plundered the companies to the detriment of any outside shareholders, real or potential." Mark Whitehouse, The Other Side of the Room, MosCow Times, Sept. 16, 1997. When insiders gut a firm, they could be failing to maximize residuals according to several of the pathologies we identify as well as making non pro-rata distributions. 
failure to maximize residuals has the same effect, indeed even more directly. The vast transition literature never makes clear which failure dominates in any particular enterprise fiasco. Instead, bad corporate governance becomes a catch-all for problems that should be understood as being quite distinct. Pinning down these distinctions should help when we come to prescribing policy cures.

A cautionary methodological note is in order at the outset, however. The study of corporate governance in Russia is hampered by two problems. First, serious firm level econometric study of corporate governance changes in Russia is difficult or impossible because meaningful hard data on enterprise behavior is hard to come by. Firms do not publish serious accounts of their own performance because managers hide their own ongoing thefts of firm assets from outside shareholders and from others who would seek to steal those assets themselves, including labor and the mafia. Also, back tax debts, which pervade the corporate sector, mean that any reported income may be seized, making the effective tax rate 100 percent. So most income statements and balance sheets are fictional, making it difficult or impossible to undertake serious firm level econometric study of corporate governance changes. Second, econometric work testing propositions about corporate governance based on country level comparisons of economic performance is difficult as well. Good corporate governance is neither a necessary nor a sufficient condition for achieving a developed capitalist economy, it simply helps. Italy, for example has a vibrant economy even though the governance of its corporations would generally fall far short of the standards set out here. ${ }^{10}$ Russia, in contrast, would likely continue to languish economically absent solving some of its other pressing problems even if its firms all fully met these standards. The sample size of countries is small relative to all the other factors that affect national economic performance. These two problems mean that we are left with anecdotal accounts and surveys as our main sources of empirical information. These sources involve their own biases; nevertheless, they suggest a reasonably coherent picture. Informing this picture with theory tells what we believe to be a convincing story.

\section{B. The Failure to Maximize Residuals}

10 See Luigi Zingales, The Value of a Voting Right: A Study of the Milan Stock Exchange, 7 REV. ECON. STUDIES 125 (1994) (Suggesting that the huge control premium for shares of Italian firms shows a poor corporate governance regime). 
We can identify five distinct pathologies indulged in by loosely constrained, poorly incentivized managers that result in firms failing to maximize residuals. ${ }^{11}$ We focus first on this prong of bad corporate governance because it is crucial to explaining why insiders do not operate their firm even to maximize their own joint benefit, an important issue we take up in Part II.B. As we shall see, the initial structure of ownership makes Russian firms particularly vulnerable to exhibit these corporate governance pathologies. When the initial ownership structures intersect with untenable firm boundaries, the pathologies we identify here become even more intractable.

Pathology 1: Continued Operation of Value-Destroying Firms. - Any economy has some unreformable value destroying firms that should be shut down immediately. Continued operation of these firms, even if undertaken as efficiently as possible, represents a negative net present value decision from a social point of view: operation in the current period results in a social loss too great to be offset by social gains, if any, from continued operation in subsequent periods. ${ }^{12}$ Despite the social harm, institutional arrangements in an economy may nevertheless permit such a firm to continue operating. For example, in Russia, consider the case of the Tutayev Engine Factory, which continues to operate despite the plant manager's estimate that "it costs the plant about 1.33 rubles to produce about 1 ruble in output."13 In the case of many unreformable value destroying firms, poor corporate governance is the main cause of their continued operation, hence the reason for identifying this problem as the first type of potential corporate governance pathology. Firm managers wish for continued operation so they can hold onto their jobs and associated perquisites. Because they

11 Note, we continue to assume that the firm purchases its inputs and sells its outputs in competitive markets and that there are no important externalities or subsidies. Therefore, the firm's input costs should reflect the social opportunity costs of continued operation and output prices the social benefits of production.

More precisely, for a firm to fall into this category, two requirements must be met. First, the social benefit from the firm's output in the current period must be less than the social cost of its inputs. Second, after comparing for each subsequent period the social benefits and costs, and discounting the difference to present value, the aggregate of these discounted differences must be either negative or, if positive, less than the deficit in the current period. In terms of current operations, this assumes that the firm operates at lowest possible cost for the level of output chosen and that it chooses the level of output that will maximize its residuals. In terms of decisions made in the current period that affect future periods, this assumes that the firm follows an optimal investment policy, which commonly would be undertaking no investment at all.

13 Maura Reynolds, A Russian Company Town's Miracle, L.A. TIMES, Mar. 5, 1999, at A1. 
are not constrained by effective corporate governance mechanisms, the managers get their way. In other cases though, good corporate governance is not necessary to shut down a firm that should in fact be closed. And in yet other cases, good corporate governance is a necessary but not sufficient condition to close the firm. Making these distinctions is important for good policy making.

a. When is corporate governance relevant? Retain the assumption for a moment that an unreformable value destroying firm purchases inputs and sells outputs in competitive markets, that there are no important externalities, and that credit and other finance is extended to firms only on a reasonably informed, rational basis. Even with no new investment, such a firm's ordinary operations result in a negative cash flow in the current period (one that is sufficiently negative that expected future cash flow, discounted to present value, would, even if positive, be unable to offset). The firm would thus lack enough current cash flow to purchase the inputs its needs to continue production and would lack cash flows in the future to use as a basis to obtain credit or other finance sufficient to cover this deficit.

The importance of corporate governance here depends entirely on whether the firm has any cash reserves or assets with significant salvage value. Without reserves or salvageable assets, the firm would be forced to close immediately regardless of how much its managers want to continue operations and regardless of how ineffective existing corporate governance mechanisms were in restraining them. Russia's generally outmoded capital stock implies that many firms lack assets with any significant salvage value. There is also a general cash shortage. Thus, absent subsidies and problems in the way credit is extended, many firms whose continued operation is value destroying would shut down promptly even though the corporate governance regime is highly ineffective. Neither improved corporate governance nor an effective bankruptcy regime is necessary to eliminate such firms.

On the other hand, for firms with reserves or salvageable assets, effective corporate governance is necessary to shut down the firm immediately. Otherwise managers can indulge their desires to continue the operation. Where cash reserves are available, the cash can be used directly to buy the needed inputs. Where the firm has salvageable assets, cash can be raised by selling the assets or using them as a basis for gaining credit. Many value-destroying Russian firms do have assets with significant salvage value. Manufacturing businesses, for example, are often located inside large cities on real estate with far more value in other 
uses. $^{14}$ If the firm has a negative cash flow, its managers may nevertheless be able to keep operating by cashing out the salvage value of these assets to acquire needed inputs. Even with a positive cash flow, closing the firm may be socially desirable once the rental value of the land is properly counted as an opportunity cost.

$b$. The role of subsidies and inappropriate credit and finance. Now drop the assumptions made above concerning subsidies, credit and finance. Where there is a subsidy, or credit or finance is extended on other than a reasonably informed and rational basis, a firm can have a positive cash flow even though the social benefit from the firm's output can be less than the social cost of its inputs. Under such circumstances, the firm's continued operation, even though involving a social loss, can be perfectly consistent with maximizing residuals. Corporate governance mechanisms that push a firm's managers to maximize residuals will not by themselves lead to the socially desirable result of closing down these firm. Indeed, for firms without reserves or salvageable assets, the quality of corporate governance is not even relevant. Such firms will be shut down, regardless of the quality of corporate governance, if and only if the subsidies or inappropriate credit provision is ended.

Russia continues to provide many subsidies, particularly in the energy area. Also, the system by which input suppliers are paid, often involving barter, is highly chaotic, implying that credit is often not extended in a rational, well informed fashion. And workers have often become involuntary creditors when firms do not pay them and let back wages arrears pile up. ${ }^{15}$ All this suggests that many Russian firms are continuing to operate that should be shut down immediately - but improved corporate governance will not, or will not by itself, solve the problem. Instead, elimination of subsidies and improvement of the credit process are the relevant reforms.

In sum, Russian firms that should be shut down immediately fall into three groups. The first are firms with no cash reserves or assets with significant salvage value and which benefit from no subsidies or

14 WORLD BANK: RUSSIA HOUSING SECTOR REFORM, 1994 (land chapter).

15 For purposes of this analysis, workers can be considered involuntary creditors, however, only for the wage arrears that have accumulated during the period before sporadic wage payment became their firm's ordinary and usual behavior. Once the pattern of sporadic payment becomes expected and there is no reasonable prospect that the arrears are going to be paid, the practice is more appropriately viewed as a de facto wage reduction. At that point, the decision of workers to stay in the firm's employment suggests that the alternatives available to them were no more desirable. Thus the de facto lower level of wages is presumably a reasonable measure of the social opportunity cost of their labor. 
unsuitable credit extensions. These firms are presumably closing on their own, no matter how bad their corporate governance mechanisms. The second group are firms with no cash reserves or assets with significant salvage value but which do benefit from subsidies or unsuitable credit extensions. Given the pervasiveness of these problems in the economy, particularly the provision of energy at below world market prices, this second group may be much larger than the first. ${ }^{16}$ If the subsidy and credit problems are effectively addressed, these firms will close promptly but not before. Improvements in corporate governance will have no effect on this second group. The third, also large group includes firms with cash reserves or assets with significant salvage value that also benefit from subsidies or unsuitable credit extensions. These firms will not close until there is both an improvement in corporate governance and an end to the subsidies and unsuitable credit extensions.

c. The ZiL Example. Moscow's ailing ZiL truck company is a useful example of a firm in the third group. The company is a "dinosaur" 17 that continues to produce many of the same poor quality trucks as it did under the Soviets, despite the trucks' terrible reputation and scant market. ${ }^{18}$ As one reporter notes:

The total amount of [post-privatization] state assistance to $\mathrm{ZiL}$ through various channels is estimated at approximately $\$ 100$ million. . . . [T] he plant never regarded the money it received as credits that had to be paid back. While receiving money for the production of trucks that customers were unwilling to pay for, ZiL continued to ship them out. . . . [F]rom force of old Soviet habit, it kept pushing to fulfill a plan that was long gone, at a time when it should have been cutting production and thinking about structural reorganization. ${ }^{19}$

16 The Soviet Union built its whole manufacturing sector based upon energy resource subsidization. These subsidies continue to a considerable extent even today through provision of these resources at prices below the world level, a fact that is somewhat disguised by the prevalence of barter transactions. Most of the firms that resulted from the privatization of this sector would be unprofitable in an open economy. [cite to Barry Ickes Foreign Affairs article]

17 Peter Galuszka \& Patricia Kranz, Look Who's Making a Revolution: Shareholders, BUSINESS WEEK, Feb. 20, 1995 ("turning out the same basic truck for 30 years").

18 Michail Berger \& Dmitry Dokuchayev, Divided Authority at ZiL: The Giant Can No Longer Live in the Old Way but Doesn't Yet Want to Live in the New Way, IZVESTIA, Apr. 16, 1996, translated in 48 CuRRENT Digest OF THE POST-SOVIET PRESS, May 15, 1996, at 10.

19 Id. (Internal quotation omitted). See also James Rupert, Post-Poll Jitters for 
As the company continued to fall apart, Moscow Mayor Yury Luzhkov acquired for the city a controlling stake in the firm, but kept incumbent management in place. ${ }^{20}$ Rather than closing the firm and liquidating its main assets, the Mayor instead began ordering city services to buy ZiL vehicles. $^{21}$ He also secured a large new line of credit on the basis of the firm's main asset, "tens of hectares of prime land in south Moscow with a potential market value of hundreds of millions of dollars." ${ }^{22}$ The Mayor's plans were to relocate the firm's production facilities, sell 49year leases to some of the land raising about $\$ 35$ million, and then transfer the new funds to the company rather than to shareholders or to more viable firms. ${ }^{23}$ But as one commentator suggests, "it is not clear that even Luzhkov can create a market for ZiL trucks.",24

Shutting down the firm at the outset would likely have been the residual maximizing decision. The government could have targeted its limited subsidies to providing a social safety net for workers, ${ }^{25}$ and the

Russian Industry, INT'L HERALD TRIB., July 6, 1996 ("If Mr. Yeltsin now gets serious about ending state support for dying industries, ZiL faces desperate times. Despite having been privatized, the plant seems to be having trouble weaning itself from Sovietstyle subsidies.").

20 The City increased its stake to $60 \%$ by buying the $30 \%$ stake previously owned by Microdin, the main outside shareowners who had, for a short period brought in new management, before the city government, labor, and the old managers intervened. Sergey Lukianov, Mayor Pulls Out Stops to Rescue ZiL, Moscow TiMES, Sept. 27, 1996; Elizabeth Sullivan, Reforms Sour for Disenfranchised, Plain Dealer, June 6, 1996 (outside managers were "forcibly escorted off the premises by the security forces of the old").

21 ZiL Takes Alternative Road to Capitalism, RUSSIA EXPRESS BRIEFING, Jan. 13, 1997; Paul Funder Larsen, Buying Land is Next Hurdle for Private Firms, Moscow TIMES, Nov. 26, 1996.

22 Larsen, supra note * ("Most of Russia's 120,000 privatized firms do not own the land they stand on. They do not even have a clear lease agreement. Instead they occupy land under a Soviet-era concept of temporary management which gives city officials a big say in how the land is used and gives companies few rights to sublet, sell, or redevelop."). C $f$. Michael A. Heller, The Tragedy of the Anticommons: Property in the Transition from Marx to Markets, 111 HARV. L. REV. 621 (1998) (identifying anticommons in fragmented ownership in Russian enterprise assets). See also Sergey Lukianov, Mayor Pulls Out Stops to Rescue ZiL, Moscow TimeS, Sept. 27, 1996 (rescue plan includes local and federal tax breaks, direct subsidies, guaranteed purchases of ZiL output by the city, and auctioning some ZiL real estate, "with 70 percent of the proceeds going to the company and 30 percent to the city government"). 23 Id

24 David Hoffman, The Man Who Rebuilt Moscow: Capitalist Style Could Propel Mayor to National Power, WASH. POST, Feb. 24, 1997, at A1.

25 Moscow Truck Maker Mulls Upgrade Plans, SEGODNYA, Jan. 12, 1999, translated 
land could have been sold to its highest value users at a price that would have substantially benefitted shareholders. As it was, outside shareowners "realized that, despite the municipal and federal authorities' special treatment of this flagship of the automotive industry, the enterprise was a hopeless failure, and [when] they tried to exert some direct influence on the situation ... . [it] proved to be not such an easy thing."26

Pathology 2: Failure to Use Existing Capacity Efficiently . The second type of pathology arises when continued operation, if undertaken as efficiently as possible and without new investment, would be a positive net present value decision, but operation is not done as efficiently as possible. Costs are not minimized, the best price is not obtained for a given level of output, or a non profit-maximizing output level is chosen - again, all common problems in Russia. ${ }^{27}$ Thus residuals are not maximized. Such firms should not shut down, but they should deploy existing facilities more efficiently. ${ }^{28}$ Their residuals shortfall represents a social-welfare-diminishing corporate governance failure.

Consider, for example, the Baltic Shipping Company, Russia's oldest and best known shipping enterprise. ${ }^{29}$ Under the Soviets, the firm already had wide experience working on world markets, but they relied on inexpensive Russian fuel to cover for management deficiencies that have persisted into the post-privatization period:

$[\mathrm{N}]$ early everyone admits that the management at BSC has

in BBC SuMmARY OF WORLD BROAdCASTS, Jan. 22, 1999. As it was, "the plant stopped housing construction long ago, and the plant workers, dissatisfied that they have not received the apartments once promised to them, intend to petition the International Court of Justice in the Hague." Id.

26 Berger \& Dokuchayev, supra note*.

27 As one account notes,

Eyeing [outside investors] warily are entrenched company directors, many of whom enjoy virtually unchecked command of the production lines they've presided over for decades. Outside investors allege these 'Red Directors' are used to running enterprises according to Soviet tenets: overpricing supplies, underpricing output, and pocketing the rest.

Natasha Mileusnic, The Great Boardroom Revolution, Moscow TIMES, July 16, 1996.

28 One investment banker looking over Volga Paper Co. "noticed huge, dust-covered crates packed away in the corner of the factory. They contained $\$ 100$ million worth of brand-new Austrian-made equipment. The Russians hadn't bothered unpacking the stuff." Paul Klebnikov \& Caroline Waxler, The Wild East, ForBES, Dec. 16, 1996, at 348.

29 Rachel Katz, The Strange Case of the Disappearing Ships, MosCow TIMES, May 14, 1996. 
simply not been up to the challenges of a new economy. . . . In his parting words, former president Filimonov, who retains a place on the board, pretty much admitted the management could not adapt. "Those titles we've become accustomed to hearing, such as deputy chief of finances, are simply not those functions that these people have become used to fulfilling.",30

Though the firm could be profitable today, Baltic Shipping faces a "spiral of decline" that could "lead to the company's fleet disappearing completely:"31 According to the company's foreign affairs chief, "It's difficult to say how many ships we have in operation, because at any moment, we could get another call saying another ship has been seized [by creditors]."32

The widespread existence of Pathology 2 may mask the potential extent of Pathology 1. If firms generally are not using their inputs efficiently, the marginal products of these inputs are likely to be lower, and thus, in a competitive economy, the price that needs to be paid for them and the opportunity cost of their use will be lower as well. A wholesale reduction in Pathology 2 will increase the price and social opportunity cost of at least some, and quite possibly all, major classes of inputs. ${ }^{33}$ Input price adjustments may sharply raise the number of firms displaying Pathology 1 as the increased opportunity cost of their inputs makes their continued operation socially undesirable.

Pathology 3: Mis-Investment of Internally Generated Cash Flow . - The third type of pathology arises where a firm uses its internally

$\begin{array}{ll}30 & I d . \\ 31 & I d . \\ 32 & I d . \\ 33 & I f\end{array}$

33 If the efficiency gains are spread evenly around all classes of inputs, the effect on the marginal product of each would be positive. If the gains were concentrated primarily with respect one class of inputs, for example labor, the effect on its marginal productivity is, as a theoretical matter, ambiguous. On the one hand, the gains increase the number of effective units of labor represented by each actual unit. On the other, the increase in effective units of labor relative to other inputs decreases the marginal product of each effective unit of labor. If the first effect outweighs the second, then the marginal product of labor will increase even if the more effective use of labor is the primary efficiency gain from restructuring. Whether this is the case depends of the elasticity of substitution of labor for other inputs. Empirical studies of the United States and other developed economies suggest that the elasticity is large enough that the marginal product of labor would increase even under these circumstances. For a more detailed discussion of these points, see Merritt B. Fox, Securities Disclosure in a Globalizing Market: Who Should Regulate Whom, MicH. L. REV. 2498, 2562-2569, 2630-31 (1997). 
generated cash flow to invest in new negative net present value projects. Instead of making bad investments, such a firm should instead pay out this cash flow to shareholders. Shareholders could invest these funds better elsewhere in the economy. An example of Pathology 3 includes the seemingly responsible act of using funds labeled by accountants as depreciation to replace worn out plant and equipment, if doing so is a negative net present value project. Pathology 3 can arise in conjunction with, or independent of, Pathology 2. Significant indirect evidence from two sources suggests that Pathology 3 is widespread in Russia.

First, consider the paucity of interfirm cash flows in Russia. In any economy, good investment opportunities are unlikely to be spread so evenly among existing enterprises that interfirm transfers of cash flows through the capital markets are not called for. Nor is the quality of existing firms' opportunities likely to be consistently superior to the opportunities that could be found by new firms. Thus, some existing firms (capital surplus firms) will have cash flows greater than what is needed to fund all their positive net present value projects; other existing firms (capital deficit firms) have insufficient cash flows to fund all such projects. In addition, there will exist new firms with positive net present value projects but which, by definition, have no cash flows at all. Thus, interfirm cash flow transfers are called for from surplus firms to deficit firms and new firms. In a market economy with clearly distinct firms, these transfers are accomplished when surplus firms pay dividends and deficit firms and new firms enter the capital markets, for example through the offering of new equity. In Russia, firms pay little or nothing in the way of dividends and equity finance is negligible. The lack of interfirm transfers strongly suggests that the surplus firms are instead displaying Pathology 3 and likely investing in negative net present value projects. ${ }^{34}$

The second source of indirect evidence for Pathology 3 relates to firms' failure to make pro-rata distributions of residuals. One way that

\footnotetext{
34 The lack of interfirm transfers undoubtedly is also in part due to various techniques that managers use to make non-pro-rata distributions that result in cash flow diversions to accounts that they control overseas. Because of these diversions, the firms involved have less cash, if any, available to pay dividends. To the extent that a foreign destination was chosen for these diversions because of a desire to protect what at home would have been considered stolen money or because it assists an attempt at tax evasion, the expected returns of the foreign investment funds by these diversions are likely to be lower than those of some of the unfunded projects of Russian firms. This is an example of the complex mixture of corporate governance failures in which the method by which a non-pro rata distribution is undertaken leads to a failure to maximize residuals as well, a point discussed in more detail in I.D infra.
} 
controlling shareholders can divert a disproportionate share of residuals to themselves is to have the firm invest in projects personally benefitting these shareholders. On balance, controlling shareholders may prefer to fund such projects, even if they have a negative net present value - their personal benefits more than outweigh the reduction in share value from implementing the project. Controlling shareholders will be able to indulge these preferences if the mechanisms to constrain non pro-rata distribution of dividends are weak. The abundant evidence of non prorata distributions in Russia strongly suggests that Pathology 3 is likely to be prevalent.

Pathology 4: Failure to Implement Positive Net Present Value Projects . - The fourth pathology of non residual maximization arises directly or indirectly when a firm identifies, but then fails to act on, positive net present value projects. If others do not pick up the opportunity, the firm's failure reduces social welfare as well because of the forgone chance to deploy funds to produce a return greater than their opportunity cost.

Pathology 4 is a direct result of corporate governance failures in cases where managers, due to weak control mechanisms, reject a positive net present value project because they wish to avoid personal risk. Managers tend to be risk averse because they cannot diversify away the unsystematic risk associated with any individual firm project. If managers can get away with it, they may reject projects with high expected returns if the projects have high unsystematic risk as well, even though such rejections are not in the interests of shareholders or society as a whole. By contrast, portfolio shareholders, who can diversify their holdings, are risk neutral with respect to unsystematic project-level risk. Management risk aversion causes problems everywhere, but the problems are likely accentuated in established Russian firms because incumbent managers typically internalized a high degree of risk aversion through Soviet-era careers in which punishment for major mistakes far exceeded gains from major successes. ${ }^{35}$

Corporate governance failures can also lead firms indirectly to forgo positive net present value projects. Consider a firm with willing

35 According to Blasi, Kroumova, and Kruse, the average age of enterprise directors is still over 50 years. J. Blasi, M. Kroumova \& D. Kruse, Kremlin Capitalism (1997). The OECD notes, "These directors were trained under the Soviet system. Although management skills were often important for promotion (as were political ties) during Soviet power, entrepreneurial ingenuity for successful restructuring or reorganization involving risk was usually not rewarded." OECD ECONOMIC SURVEYS, RUSSIAN FEDERATION, 1997-1998, at 158 n.171. 
managers and the prospect of a value-creating project that is nevertheless unable to proceed because financing is unavailable at a price equal to capital's social opportunity cost. ${ }^{36}$ The lack of finance may be an externality imposed by corporate governance failures in other firms. When firms generally fail to make pro-rata distributions and maximize residuals, they may severely undermine the possibility that firms with good projects can acquire financing through sales of new equity. Banks are the usual alternative source for outside finance, but in Russia, banks are providing little long-term corporate lending. The lack of a vibrant new equity market or of bank finance then proves fatal for good projects in those firms which do not generate sufficient internal funds to selffinance the project. ${ }^{37}$

In Russia, the corporate governance failures in established firms can be spectacularly large. Consider, for example the saga at Segezhabumprom, one of Russia's biggest pulp and paper mills. ${ }^{38}$ Swedish owners acquired a $57 \%$ stake in the firm; while a major pulp distributor and the Karelian regional government controlled most of the rest of the shares. Early in the relationship, when the town of Segezha had run out of fuel oil, the Swedes had agreed to "burn expensive wood

36 It is hard to get a sense of the extent of this problem for established (as opposed to new) Russian firms. Many firms face one of three choices: continued operation in its current form, massive investment to build an entirely new factory, or dissolution. Often, it seems clear that continued operation in the firm's current form would be a highly inefficient choice because there is no market for the product at prices sufficient to pay for the inputs and any opportunity costs associated with its fixed assets. And funds for a massive investment in a new factory are often not available. As a result,

The conflict between production-oriented Soviet-era management and aggressive new owners has been played out at hundreds of factories across the country. The fledgling entrepreneurs have lacked the massive capital required to make the aging red giants profitable and their attempts to make money by shutting them down and selling off their assets have proven politically explosive. As a result, privatisation has often failed to lead to restructuring.

ZiL Takes Alternative Road to Capitalism, RUSSIA EXPRESS BRIEFING, Jan. 13, 1997. It is not clear whether the lack of funds is solely due to capital market defects that arise from economy-wide corporate governance problems or whether, even without these problems, the new factory would be an insufficiently promising investment project to get funded. In general, entrepreneurs seem likely to claim the former reason.

37 Non-pro-rata distributions that result in cash flow diversions to accounts that they control overseas may also result in firms without sufficient internal resources having to forgo projects that have a positive net present value when discounted at a rate reflecting capital's true social opportunity cost. See note [ a coupe above relating to diversions] supra.

38 Doing Business in Russia: Risk and Reward in Equal Measure, FINANCIAL TIMES, Mar. 3, 1998, at 17. 
chips, normally used in paper production, to prevent the town from freezing." ${ }^{39}$ Later, the Swedes identified and committed to make over $\$ 100$ million in new investments. However, the modernization plans provoked local suspicion of job losses, prompting a campaign to force the Swedes out, an effort which included court findings that the Swedes' initial share purchases had been illegal. ${ }^{40}$ A break point occurred when the Russian co-owners - the regional government and the major distributor - refused to co-fund the working capital to keep the plant open. ${ }^{41}$ By the end, the Swedes abandoned the investment and wrote off their ownership stake, after existing managers and local government officials drove them off using "mafia-style threats against [their] staff." A story of this sort is likely to scare off even a determined large scale investor, which in most countries could protect itself using the control powers that come with large shareownership. This story is even more discouraging for individual non-control portfolio investors. As discussed further in Part II, stories like Segezhabumprom also suggest that Russian corporate law may be so weak that the results of the ordinary processes of corporate decisionmaking are not respected by officials charged with enforcing property rights. Incumbent managers appear still to have de facto property rights in assets whose title is nominally in the hands of the corporation.

Pathology 5: Failure to Identify Positive Net Present Value Projects . - The fifth type of pathology arises when a firm's managers fail even to identify positive net present value projects that the firm, through its specialization and the resulting accumulation of knowledge, is particularly well positioned to find. ${ }^{43}$ Organizational capacity to identify such opportunities is related to the incentives available to firm employees for identifying such projects as well as the incentives for them to help each other in a joint endeavor to do so. ${ }^{44}$

In the United States, venture capital significantly reduces the social costs of Pathology 5 by making available funds for promising

39 Swedish-Owned Paper Mill in Karelia Paralyzed by Fuel Shortage, RUSSIAN TV CHANNEL BROADCAST, translated in BBC SUMMARY OF WORLD BROADCASTS, Jan. 3, 1997.

40 Doing Business in Russia, supra note *, at 17.

41 Greg McIvor, Assi Hurt by Russian Plant Write-Off, FinANCIAL Times, Feb. 13, 1998, at 29.

42 Doing Business in Russia, supra note *, at 17. See also the story of Sidanko, infra note [46] and accompanying text.

43 Mark Whitehouse, The Other Side of the Room, Moscow TimES, Sept. 16, 1997.

44 See Ronald Gilson \& Joseph Bankman, Why Spinoffs, STAN L. REV. (1998). 
projects that employees identify, but managers mis-assess. Venture capital also significantly lessens the effects of Pathology 4 on the U.S. economy by making spinoffs possible in which employees proposing such projects can implement the proposal by creating a new firm, despite the employer's rejection. The possibility of getting rich in a spinoff gives employees substantial incentives to identify positive net present value projects even if they work for firms that may ultimately not implement the ideas. ${ }^{45}$ Also, when spinoffs occur, Pathologies 4 and 5 do not harm the economy because the project is implemented anyway. ${ }^{46}$

In Russia, venture capital to fund such projects is not readily available. So, Pathology 5 is likely to be more prevalent than in the U.S. and Pathology 4 is likely to be more damaging. Ronald Gilson and Bernard Black have persuasively argued that a necessary condition for developing venture capital is a vibrant equity market. But Russia will not be able to develop equity markets until most of its firms try to maximize residuals and give pro-rata distributions. Again, we see the self-reinforcing tendency of diverse corporate governance problems.

\section{The Failure to Make Pro-Rata Distributions}

The second feature of good corporate governance is that a firm makes the residuals it generates available on a pro-rata basis to the residual claimants, that is, to the common shareholders in an investorowned company. Much of modern corporate law has been built around this principle, not only rules requiring that dividends and distributions be made pro-rata but also the basic fiduciary rules policing non-arms-length transactions involving insiders and the corporation. ${ }^{47}$ In post-

45 Id.

46 A record of successful spinoffs demonstrates a failure in the finance processes of established firms and hence shows some mix of Pathologies 4 and 5. One study of the semiconductor industry shows the reason that proponents of successful spinoffs took their ideas elsewhere is that top management of employer firms simply did not perceive the ideas to be worth substantial investment. MERRITT FOX, FInANCE AND INDUSTRIAL PERformance In A DynAmic ECONOMY: TheORY, PRACTICE, AND POliCy (1987).

47 Easterbrook and Fischel argue that this statement of basic norms in corporate law needs refinement. Unequal divisions of gains from corporate activity will be tolerated, they suggest, provided that the transaction makes no shareholder worse off. FRANK H. EASTERBROOK \& DANIEL R. FISCHEL, THE ECONOMIC STRUCTURE OF CORPORATE LAW 143-44 (1991). Their refinement is valid to an extent, but whether the refinement should be stated so broadly is irrelevant to our discussion of the Russian situation. Few of the many blatant violations of the principle against non pro-rata distributions that we see in Russia could possibly be justified as necessary to permit transactions that leave no shareholder worse off. 
privatization Russia, violation of this second feature has been the most visible and widely reported symptom of bad corporate governance. Just as non-maximization comes in different flavors, Russian firms exhibit a wide range of non pro-rata distributions which we simplify into two main groups, each with many variations. Loosely, one type is what we call "diversion of claims" and the other "diversion of assets." We explore each in turn.

Pathology 6: Diversion of claims. - To give just a few illustrations ranging from blatant to subtle, managers divert control when they refuse to register share purchases by outsiders; ${ }^{48}$ refuse to recognize board directors properly elected by minority shareowners, ${ }^{49}$ dilute stock in ways that freezes out outsiders; ${ }^{.0}$ or engage in fake bankruptcies that

48 "One notorious incident involved Krasnoyarsk Aluminum, which deleted from its share register - the only legal proof of ownership - a 20 percent stake held by the British Trans World Group, effectively wiping out its holding." Natasha Mileusnic, The Great Boardroom Revolution, Moscow TiMES, July 16, 1996; David Fairlamb, Moscow Madness, InSTITUTIONAL INVESTOR, July 1995, at 30 ("Some companies think nothing of striking shareholders' names off registers if they look like they're becoming a nuisance.").

49

One long-running case involves the Novolipetsk Metal Factory, one of Russia's largest metal produces, where western investment funds were unable over the course of several years to place anybody on the board of directors, despite controlling over 40 percent of the firm's shares and despite cumulative voting rules that should have guaranteed them some voice. Mark Whitehouse, Novolipetsk Slams Foreign Investors, Moscow TIMES, Mar. 15, 1997. According to the Chairman of Novolipetsk, "In Russia's special situation, the master is, after all, not the shareholder." Id. See also Natasha Mileusnic, The Great Boardroom Revolution, Moscow TIMES, July 16, 1996; John Thornhill, Risks of Russian Market Exposed, FinANCIAL TIMES (LONDON); Mar. 25, 1997, at 2. Finally, in 1998, the outside investors were able to win seats on the board after the general director switched sides in this "marquee shareholders' rights case." Shareholders Win Two-Year Case, Can Appoint Board Members to Firm, 11 INT'L SEC. REG. REP., Jan 29, 1998.

50 Geoff Winestock, Ship Firm Managers, Shareholders Face Off in Russia, J. COMMERCE, Apr. 24, 1995, at 1A:

Managers have seen their position change dramatically over the last year with the public sale of their stock to outside investors. Shareholders, for one, have started to ask for higher profits and a voice in the company. Investors charge that management decided on a simple solution to the problem. They unilaterally issued themselves enough shares to take back control of their companies.

Id.; see also Gary Peach, Financial Ethics Crackdown Bodes Well for Shareholders, Moscow TIMES, Feb. 24, 1998 ("Dalmoreprodukt, Russia's largest seafood exporter, is in the process of watering down outsiders' interests by means of an insider share issuance for select major shareholders, managers, and employees."). 
wipe out shareowner's interests. ${ }^{51}$ The key feature of these non pro-rata distributions are that the people perpetrating them, usually insider ownermanagers, are keeping the firm intact, including its assets and opportunities. They gain instead by manipulating the corporate legal system, the bankruptcy law, and other laws to reduce or eliminate the claims of some or all of its shareholders on the firm's residuals - usually wiping out the outside minority shareholders. As one investor put it, "A 51 percent shareholding interest in a Russian company conveys to the owner a license to steal from the remaining 49 percent." ${ }^{52}$

In one notorious case that has dragged on for years, the incumbent manager at Kuban Gypsum-Knauf refused to vacate even though he had been fired by the majority owners, a German company. ${ }^{53}$ Supported by the local government, the manager installed Cossack guards, held his own shareholder meetings, locked out the owners, diluted the owners' stock, and ignored dozens of court rulings against him over the years. ${ }^{54}$ Finally, and for the first time in Russia, the German owners were able to wrestle their way back in, following intervention by a commission headed by the Prime Minister. ${ }^{55}$ According to one Knauf lawyer, "It's a sort of legal nihilism. The farther from Moscow, the less attention they pay to the legal side of things. There is no understanding of a final court order.",56

And managers are not the only ones diverting control. Recent reports suggest that local and regional governments with minority share interests have begun engaging in the same game, forcing firms into

51 See, e.g., Kranz, supra note *, at 44 ("In regions across Russia, both local governments and creditors have filed bankruptcy suits against subsidiaries of Potanin's Sidanko Oil. The suits ostensibly seek payment of back taxes and delinquent energy bills. But the real prize could be Sidanko's oil assets.”); Andrew Higgins, The Lion's Share: As One Bank Shows, Bankruptcy in Russia is a Real Cat Fight, Wall St. J., Apr. 5, 1999, at A1 ("Just as Russia's earlier drive to put state property in private hands often yielded cozy inside deals instead of a spur to efficiency, bankruptcy has mutated into a cat fight often involving shadowy deals and allegations of asset stripping. 'Many enterprises are being artificially bankrupted, to be taken over by some groups,' Prime Minister Yevgeny Primakov [said.]").

52 Investor Hell, J. COMMERCE, June 15, 1998, at 6A.

53 Lyudmila Leontyeva, Red Director's Stronghold in Kuban, Moscow NEWs, Oct. 30, 1997.

54 Mark Whitehouse, Germans Cry Foul In Gypsum Plant Feud, Moscow TIMES, Nov. 29, 1997; Mark Whitehouse, Under Seige, Moscow TimES, Dec. 9, 1997.

55 Katy Daigle, Nemstov Hails Win for Investors' Rights, MOSCOW TIMES, Mar. 10, 1998.

56 Mark Whitehouse, Take 'Em to Court, Moscow TIMES, Feb. 10, 1998(quoting Knauf lawyer). 
bankruptcy over unpaid taxes, and then asserting control, essentially a form of renationalization in cases where tax rates are absurdly high, exceeding $100 \%$ marginal rates. Also, outside shareholders such as those associated with financial-industrial groups (FIGs) may seize control of firms, replace managers, and then also freeze out minority share holders, including employees.

Many of these tactics are familiar to students of the history of western corporate law, but in Russia this game seems limited only by the creativity of those controlling the firm: the Russian regulatory apparatus has been notoriously ineffective in controlling such diversions. To give one example, in late 1997, insider shareholders had Sidanko Oil company offered exclusively to themselves for nominal consideration a form of bonds that were convertible into Sidanko shares. ${ }^{57}$ Once the conversion occurred, the remaining shareholders would see their ownership stake diluted down to one third of their original claim, yet the company gained no significant new assets. The only unusual aspect of this share dilution was that for the first time in its history, the Russian Securities and Exchange Commission, in the glare of particularly intense negative press about the scheme, intervened in early 1998 to block the issuance of the convertible bonds. As a result, the majority insiders agreed to negotiate with minority share holders. Such regulatory oversight has been extremely rare, not a regular event in the Russian scene. But, even this victory was Pyrrhic. Since then, the owners of Sidanko Oil have apparently forced it into a fake bankruptcy, effectively freezing out another major shareholder, British Petroleum, which had invested $\$ 500$ million in the firm for a 10 percent ownership stake, a stake now apparently worthless despite the quite valuable assets that the reorganized firm will control.

Pathology 7: Diversion of assets . - The second major class of non pro-rata distributions, and the last pathology in our framework, involves direct diversion of assets and opportunities belonging to the firm. The key feature of this type of corporate governance failure is that insiders leave the ownership structure intact as they hollow out the firm. For managers, diversion of assets may be accomplished by outright looting of the firm - taking cash or assets belonging to the firm and effectively giving title to the insiders. Or it may take the form of

\footnotetext{
57 See Jeanne Whalen, Shareholders Rights: Round 2, Moscow TiMES, Feb. 17, 1998; Jeanne Whalen, FSC Cracks Down on Yukos, Sidanko, MosCow TiMES, Feb. 19, 1998 (FSC action perhaps marks a "turning point"). In the interests of full disclosure, the authors of this article should state that they served as consultants to some minority share holders in this matter.
} 
sweetheart business deals with firms controlled by insiders or their families, ${ }^{58}$ using, for example, transfer pricing agreements that move profits to subsidiaries or parents in which the insiders have a larger interest. $^{59}$ According to one report, "Protecting sweetheart financial deals is behind much of the hostility to outside investors. Virtually every Russian enterprise, big or small, is surrounded by 'independent' companies set up by managers or their families. In many cases, sales and purchasing contracts are structured to go through these firms, raking off profits from the main enterprise." 60

Russian firms also engage in non pro-rata distribution of residuals when they continue to pay for redundant shareholder employees and when the firm provides public services without compensation or relief from reasonably and equitably imposed tax obligations. The experience of Tatneft shows a simple but creative form of non pro-rata distribution in favor of a local government shareholder. According to one report,

Tatneft is the victim of parasitism, pure and simple. . . .

[Regional government] bureaucrats who control the firm were under orders to borrow as much money as possible on international capital markets to support the region's economy and the government's pet programs. . . . The company piled on almost $\$ 800$ million in debt in 1997 alone, and now has over $\$ 1$ billion of the stuff on its balance sheet. Tatneft was forced to make sizeable loans to the regional government (now broke). ${ }^{61}$

Neither the diversion of assets, nor diversion of claims noted in the previous section, necessarily decreases social welfare in a static analysis - the diversions merely redistribute wealth from one group of

58 Katy Daigle, Bill Improves Shareholder Rights in Russia, MosCow TIMES, July 14, 1998 ("In Russia, company directors and managers are routinely accused of insider dealing, which includes everything from accepting bribes to act against their company's interests to selling assets or shares to relatives or friends.").

59 See, e.g. Jeanne Whalen, Shareholder Rights: Round 2, Moscow Times, Feb. 17, 1998 (discussing transfer pricing at Tomskneft, one minority shareholder protested, "Tax debts and the cost of production are left with the subsidiaries, while profits are illegally upstreamed to the parent."); Jeanne Whalen, Navigating the Russian Subsidiaries Minefield, Moscow TIMES, Mar. 10, 1998 ("Share swaps aside, transfer pricing is the practice most feared by subsidiary shareholders. Holding companies force subsidiaries to sell their oil at below-market prices, and then resell it for a profit that is kept by the holding company.").

60 Patricia Kranz, Shareholders at the Gate, BuSINESS WEEK, June 2, 1995, at 60.

61 Gary Peach, Poor MANAGEMEnT Destroys SberbanK, TATNEFT, MGTS, MosCow Times, Dec. 15, 1998. 
owners to another. But moving to a dynamic analysis changes the story. If outsiders cannot trust that they will get pro-rata distributions, then they will be unwilling generally to treat shares as financial assets, and they will be unwilling to provide equity finance in exchange for anything less than total control. So the prevalence of diversion imposes a substantial externality on the Russian enterprise sector. Because potential outside investors cannot protect against ex post diversions of their investments in firms that turn out to be successful, outsiders have little ex ante incentive to invest on terms that would be appealing to firms with positive net present value projects.

\section{A Simple Framework Meets Complex Failures}

Table 1 below summarizes our framework of Russia's corporate governance pathologies. Real world cases do not fit neatly into one or another of the boxes we describe here, but rather represent complex mixtures of several failures. To start, if managers that are not sufficiently constrained or incentivized to prevent them from diverting claims, they may be similarly able to divert assets - both types of diversion may be undertaken at once, often in ways that are hard to tease apart. $^{62} \quad$ For another complex diversion example, see Alan S. Cullison, Russian Share Shuffle Maddens Investors, WALL ST. J., July 23, 1999, at A12 (discussing Yukos Oil company's quiet transfer of the bulk of its two most valuable petroleum-producing assets to offshore entities). See also Alan S. Cullison, Yukos Transfers Two Oil Units to Offshore Firms, WALL ST. J., June 4, 1999, at A12 (noting earlier part of saga where the tycoon who controls Yukos had "barred minority investors from shareholder meetings at three Yukos subsidiaries and pushed through permission for massive share issues that will dilute investors' holdings"). Next, there is a potential interaction between the failure to make pro-rata distributions and the failure to maximize residuals. Some tactics used to effect a non pro-rata distribution of a

62 Consider the recent looting of the Moscow City Telephone company (MGTS). Even though it is the largest telecommunications company in Russia, its share price has dropped 95\% from its high. According to one report, majority ownership was transferred from a public body to a "secretive outfit that has links both political and economic to Moscow Mayor Yury Luzhkov. Any growth potential for the stock has thus been eliminated. . . . [I]t is safe to say that [the new owners] have no concern for shareholders of MGTS. What [they] care about, though, is getting Luzhkov elected to the presidency, so MGTS' available cash will be utilized accordingly." Gary Peach, Poor Management Destroys Sberbank, Tatneft, MGTS, Moscow Times, Dec. 15, 1998. See also Gary Peach, Mayor's Industrial Policy Carries Big Costs, Moscow TIMES, Dec. 8, 1998 (noting that diverting control of "prize municipal assets" ensures that these firms "bountiful cash flow" will be available to help Luzhkov "meet the presidential challenge in 2000"). 
firm's wealth have no direct effect on residual maximization. This would generally be true of diversion of claims and of brazen, outright theft of assets. Other tactics however, do reduce a firm's residuals, for example when owner-managers grant themselves unjustifiably large perquisites, make non-arms-length sweetheart deals involving the company and its insiders, ${ }^{63}$ and engage in direct thefts of assets that require considerable efforts to cover up.

\section{TABLE 1: Framework of Russian Corporate Governance Pathologies}

\begin{tabular}{|c|c|}
\hline \multicolumn{2}{|c|}{ I. Non-Maximization of Residuals } \\
\hline $\begin{array}{l}\text { Pathology } 1 \text { : } \\
\text { Unreformable value- } \\
\text { destroying firms fail } \\
\text { to close }\end{array}$ & $\begin{array}{l}\text { Arises when an unreformable value-destroying firm can } \\
\text { dissipate cash reserves or salvageable assets. Corporate } \\
\text { governance is not the key issue when firm has no reserves or } \\
\text { salvageable assets, or when subsidies or unsuitable credits } \\
\text { are present. }\end{array}$ \\
\hline $\begin{array}{l}\text { Pathology 2: } \\
\text { Viable firms fail to } \\
\text { use existing capacity } \\
\text { efficiently }\end{array}$ & $\begin{array}{l}\text { Arises when continued firm operation, if undertaken as } \\
\text { efficiently as possible and without new investment, would } \\
\text { be a positive net present value (NPV) decision; but costs are } \\
\text { not minimized, the best price is not obtained for given } \\
\text { output, or a non profit-maximizing output level is chosen }\end{array}$ \\
\hline $\begin{array}{ll}\text { Pathology } 3: \\
\text { Firms } & \text { misinvest } \\
\text { internally } & \text { generated } \\
\text { cash flows } & \\
\end{array}$ & $\begin{array}{l}\text { Arises when a firm uses internally generated cash flow to } \\
\text { invest in new negative NPV projects instead of paying out } \\
\text { this cash flow to shareholders who could invest the funds } \\
\text { better elsewhere in the economy. }\end{array}$ \\
\hline $\begin{array}{l}\text { Pathology 4: } \\
\text { Firms fail to } \\
\text { implement positive } \\
\text { NPV projects }\end{array}$ & $\begin{array}{l}\text { Arises when a firm identifies but then fails to act on positive } \\
\text { NPV projects. Managers tend to be risk averse because they } \\
\text { can't diversify away unsystematic risk of a firm's project. If } \\
\text { others do not pick up the opportunity, the firm's failure also } \\
\text { reduces social welfare. }\end{array}$ \\
\hline $\begin{array}{l}\text { Pathology 5: } \\
\text { Firms fail to } \\
\text { identify positive NPV } \\
\text { projects }\end{array}$ & $\begin{array}{l}\text { Arises when a firm's managers fail to identify positive NPV } \\
\text { projects that the firm is particularly well positioned to find. } \\
\text { The possibility of venture financing and spinoffs can reduce } \\
\text { the prevalence and social costs of this pathology. }\end{array}$ \\
\hline
\end{tabular}

63 The perquisites are unlikely to give the insiders as much utility as the cash that they cost would. Michael C. Jensen \& William H. Meckling, Theory of the Firim: Managerial Behavior, Agency Costs and Ownership Structure, 3 J. FIN. ECON. 305 (1976). The sweetheart deals are unlikely to be with the least cost provider of the service or good needed. 


\begin{tabular}{|c|c|}
\hline $\begin{array}{c}\text { Pathology 6: } \\
\text { Firms fail to prevent } \\
\text { diversion of claims }\end{array}$ & $\begin{array}{c}\text { Arises when some residual owners of a firm manipulate } \\
\text { corporate, bankruptcy, and other laws to shift ownership } \\
\text { away from other residual owners - often by diluting shares } \\
\text { held by outside minority shareholders. }\end{array}$ \\
\hline $\begin{array}{c}\text { Pathology 7: } \\
\text { Firms fail to prevent } \\
\text { diversion of assets }\end{array}$ & $\begin{array}{r}\text { Arises when some residual owners privately appropriate } \\
\text { assets and opportunities belonging to the firm, but leave the } \\
\text { firm's formal ownership structure intact. }\end{array}$ \\
\hline
\end{tabular}

Finally a management intently focused on, and especially skilled in, diversions may have neither the time nor the ability to give adequate attention to maximize residuals as well. Consider AutoVAZ, Russia's largest automaker. The company evidences several of the pathologies of non residual maximization: they continue to employ 114,000 workers and essentially comprise the town of Togliatti; production takes 450 worker-hours per car, compared with 15 worker-hours for Toyota; seven of ten current production models were designed in the 1970s; the firm lacks working capital; and the size of the plant makes changeover to new production extremely expensive. ${ }^{64}$ Poor management undermines the company in many ways: working capital disappears, "insider deals and criminal groups sap would-be profits, and attempts at reform have been half-baked at best." 65 According to one analyst, "The company is going

to die a death by a thousand cuts. It's just going to sit there until someone sees the potential value in some of its assets, strips them out and creates a different franchise or does a complete management overhaul. ${ }^{66}$ With its mix of management failures, the company became the country's largest tax laggard. ${ }^{67}$ To get an extension on tax arrears, the firm guaranteed that it would dilute its stock enough to give $51 \%$ of voting shares to the government if the firm missed two tax payments. ${ }^{68}$ But then the firm proved unable to finish cars because, "almost the entire amount of income [was] used to pay taxes." $"$ After missing several tax

64 Alexander M. Jenkyn, Russian Auto Manufacturers, Hobbled by Inefficient Management, Look to Foreign Investors, EAST/WEST EXECUTIVE GUIDE, May 1, 1997.

65 Mark Whitehouse, Slow Death, Moscow TIMES, June 16, 1998 (a lengthy account of AutoVAZ's management difficulties and slow decline).

66 Id. (quoting Victor Frumkin, an automobile analyst).

67 Russia's Nemtsov Threatens Asset Seizures, Bankruptcies over Huge Tax Arrears, AFX NEWs, Sept. 23, 1997.

68 Autovaz to Issue New Shares, RUSSIAN BUSINESS NEWS UPDATE, Sept. 1, 1997.

69 Auto Giant Labors Under Tax Burden, ITAR-TASS, translated in BBC SUMMARY OF WORLD BROADCASTS, June 5, 1998 (quoting Autovaz's Chairman of the Board). 
payments, Autovaz agreed to what amounts to renationalization. ${ }^{70}$

\section{The Role OF INITIAL CONDITIONS IN RUSSIAN PRIVATIZATION}

The preceding discussion establishes the severity of corporate governance problems in Russia and the mechanisms by which these problems inflict damage on the real economy. Standard explanations of these corporate governance failures include the low level of corporate transparency, the lack of effective methods for adjudicating claimed violations of corporate law and enforcing the resulting judgments, and the absence of a network trust among Russian businessmen. While these explanations are important, they are common to all transition economies to one extent or another. We believe that to understand why Russian corporate governance problems have been so severe, it is necessary to consider the initial conditions of Russian privatization, in particular, the often untenable boundaries of newly, privatized firms and the insiderdominated ownership and control structures.

These initial conditions are unique to Russia (and the other republics of the former Soviet Union). They result from a privatization program that followed the course of least resistance. The domestic Russian architects of privatization and their foreign advisers believed it politically necessary to move quickly. As with real estate privatization, ${ }^{71}$ the initial path in corporate privatization represents not only political expediency, but also the primacy of pure economists over those more sensitive to the bargaining implications of packaging rights. The reformers hoped, naively as it turned out, that resources would naturally flow to their highest value users after markets were established. But they underestimated the roadblocks that the initial conditions would continue to impose for resource reallocation. In this Part, we detail these initial conditions and then explore how they have contributed to Russian corporate governance failures and the resulting dismal economic performance.

\section{A. Initial Conditions in Russia}

1. Untenable Firm Boundaries . - The first unique feature of

70 Kirill Koriukin, Debt-Laden AutoVAZ Hands State 50\% Stake, Moscow TimES, Dec. 31, 1998.

71 See Michael A. Heller, The Tragedy of the Anticommons: Property in the Transition from Marx to Markets, 111 HARV. L. REV. 62, 633-59 (1998) (showing how poorly conceived real estate privatization can lead to a "tragedy of the anticommons"). 
Russian privatization is the bizarrely tangled and complex pattern of firm boundaries. To crystalize the problem, we compare the way firm boundaries are defined in developed competitive economies with how they were determined during privatization in Russia.

a. Firm Boundaries in Developed Competitive Economies. Transaction cost economics provides an easy way to understand the nature of firm boundaries in a developed competitive economy. As transaction cost economists envision the world, a country's economic activities consists of a set of transactions - potentially value enhancing reallocations of goods and services - that occur between two or more parties. Every transaction that is not simultaneous and unambiguous in its implications for each party requires some kind of mechanism to govern the actions of the parties over time. In the simplest model, there are only two possible mechanisms, either an easily enforceable contract that specifies for each possible future state of nature what each party must do (referred to as a "well specified contract"), or a firm. With a firm, one party owns all the assets related to making the transaction value-enhancing. The owner enters an agreement with another party in which the owner promises compensation and the other party promises in return to do whatever, within a specified range of activities, the firm owner commands it to do. ${ }^{72}$ In this simple model, every transaction in the economy occurs in one of two places: either within a firm - i.e. it occurs under this command arrangement - or between a firm (or other individual) and another firm (or individual) pursuant to a well specified contract. A firm's boundary is defined, on the one hand, by the transactions that occur within it and, on the other, by the transactions that occur between it and others.

The least cost approach to governing some transactions is by command within a firm; for other transactions, by well specified contracts with outsiders. The central tenet of transaction cost economics is that in a competitive economy, market forces push transactions toward the mechanism that minimizes governance costs, referred to as "transaction costs," a process that in turn determines firm boundaries. ${ }^{73}$ The work of transaction cost economists, suggests plausible, and in some

72 This is the simple model that underlies Coase's seminal 1937 article. Ronald C. Coase, The Nature of the Firm, 4 ECONOMICA 386. Modern work in transaction cost economics identifies a wide range of governance mechanisms in between the two extremes described in the simple model, see sources cite in notes [just below ] infra, but the simple model is sufficient to illustrate the important points in the discussion here.

73 Oliver Williamson, Corporate Governance, 93 YALE L.J. 1197, 1200 (1984). 
instances empirically verifiable, reasons why in developed competitive economies we see the existing pattern of firm boundaries. ${ }^{74}$

b. Firm Boundaries in Russia. - In Russia, the privatization process created an initial set of firms that divided up national economic activity in ways largely unrelated to the concerns of transaction cost minimization. Each privatized firm had a management team, workers, assets, and product mix that roughly corresponded to an administrative unit in the old Soviet economy. Often this unit was largely geographically based, so that a firm might encompass all the economic activity occurring within a given town or district, including perhaps a major enterprise such as auto manufacture, activities constituting any locally produced inputs for that enterprise, and other activities that simply met the consumption needs of local residents, such as a dairy or bakery. The firm was also often highly integrated horizontally, being the only such firm in the country, or one of only a few, that produced its main product, even though in many cases scale economies did not require such a high level of concentration. ${ }^{75}$ The boundaries of such a firm may (or may not) have made sense within a centrally planned and managed economy, but they in no way correspond to the boundaries that would minimize transaction costs in a competitive market economy.

Severstal, one of Russia's largest steel companies, illustrates the plight of large employers in one-factory towns. The company's 48,000 employees make up the dominant wage base of Cherepovets, a city of 300,000; and the firm alone contributes more than one-third of the regional government's budget. ${ }^{76}$ Even though the company is headed by an "energetic 31-year-old general director, who was elected by

74 For representative work, see OLIVER WILLIAMSON, THE ECONOMIC INSTITUTIONS OF CAPITALISM (1985); Benjamin Klein, et al., Vertical Integration, Appropriable Rents, and the Competitive Contracting Process, 21 J. LAW \& ECON. 297 (1978). Oliver Hart's "property rights" approach further explains the forces that define firm boundaries in a competitive economy. Hart builds on the transaction cost approach by exploring in more detail exactly what changes when the same transaction occurs within a firm instead of between firms. See Oliver HART, Firms, CONTRACTS, AND FinANCIAL STRUCTURE, 13-91 (1995).

75 Putting issues of market power aside, there is in any given industry an optimal firm size that involves a tradeoff between scale economies (to the extent they exist) and the managerial incentive problems that tend to grow with firm size. See HART, supra note *, at 51 .

76 See Stephanie Baker-Said, Steel Mill Begins Crawl to Productivity, Moscow Times, June 2, 1997; Neela Banerjee, Russian Firm Controls Elections, Profits By Buying City's Media, Dallas MornING News, June 15, 1997, at 16A ("almost everyone works for the steelmaker or has a relative who does"). 
shareholders," 77 the firm faces numerous difficulties raising capital, shedding labor, and spinning off apartments and other social services. The director notes, "The economy of Cherepovets largely depends on Severstal. Employment is an important issue, especially in this time of political uncertainty., 78

A firm such as Severstal, with poor firm boundaries, massive over-employment, and increasingly obsolete equipment, cannot drum up much outside investor interest even with a relatively benign corporate governance reputation. ${ }^{79}$ "Outside bidders for the stake would be taking a risk by buying into a company with a closed management style." $\$$ Recently, the regional office of the State Property Committee decided to sell its 10 percent share in the company, but the only likely bidders are the insider management whose current share is a "well-guarded secret." 81 Most likely, acquiring the 10 percent would boost management from its current majority control position to over 75 percent at which point it would have "absolute control," 82 of the company, free of many protections for minority shareholders. ${ }^{83}$ Thus, we get a preview of how poor firm boundaries can lead to potential corporate governance problems and inflict more economic damage than simply the increased transaction costs they cause.

2. Dominance by Insider Groups . - a. Insider Control Before

77

Id.

Patrick Ninneman, Growth in China and India; Turmoil in Russia; Discussions During the 1997 Steel Survival Strategies Conference, 13 NEW STEEL 76 (Aug. 1997).

79 According to one firm analyst, "Severstal does not have a track record of either cheating investors or treating them fairly. They are not interested in the capital markets, but at the same time they don't engage in share issues or transfer pricing to the extent that other companies do." Brian Humphreys, State to Sell 10\% Stake in Northern Steel Plant, Moscow Times, May 12, 1998 (quoting Kakha Kiknavelidze, a metals analyst).

80 Id.

81 Brian Humphreys, State to Sell 10\% Stake in Northern Steel Plant, Moscow TIMES, May 12, 1998.

$82 I d$.

83 The insiders may secure absolute control, not just of the firm, but also of the surrounding governments. The firm's odd boundaries make it particularly vulnerable to political depredations by local and regional governments. Rather than restructure, the firm has defended itself by buying all of the newspapers, radio and television stations in the region, even though they are for the most part unprofitable. Neela Banerjee, Russian Firm Controls Elections, Profits By Buying City's Media, Dallas MoRnING NEWS, June 15, 1997, at 16A. These captive media then backed company-sponsored candidates who captured all the city's elected positions and then "voted to cut Severstal's property taxes retroactively for all of 1996, despite budget shortfalls. The decision saved the company several million dollars in taxes." Id. 
Privatization. Russia has a long history of control by a combination of management, labor representatives and local government insiders. During the Soviet era, central planning and ministry supervision disciplined insiders' decision-making, to some extent. Beginning with Gorbachev's reforms in the late-1980s and Yeltsin's reforms in the early 1990s, central ministry control was loosened without installing any outside monitor as a replacement. Managers quickly came to idea that enterprises needed an owner, and that they indeed were that owner. ${ }^{84}$

Before firms were privatized, they went through an intermediate step called "corporatization," in which the enterprise was formally created as an incorporated business unit with a separate legal identity, a board of directors, senior management and a notional economic value ascribed to its assets. ${ }^{85}$ When a firm was corporatized, the state owned 100 percent of its stock, but central ministries lost day-to-day control. During this pre-privatization stage, boards of directors explicitly divided control among the general director who received two votes, rank-and-file workers who received one vote, and the local and federal governments who each received a vote. ${ }^{86}$ The employees elected the senior management during this period, but employees rarely exercised their power in anything but the most nominal sense. By cooperating with or intimidating the workers, managers positioned themselves to keep control of the firm at privatization.

b. Management-Employee Buyout Disguised as Stock Ownership. - Russia's mass privatization program of 1992-94 transferred more than 15,000 medium and large state firms to private ownership ${ }^{87}$ with "a speed that is quite unprecedented in the postcommunist world." 88 These

84 As Blasi recounts:

The Russian general director is similar in authority to the chief executive officer (CEO) of a capitalist company. . . . In the past, a Soviet ministry could hire and fire him. Once Gorbachev removed cabinet supervision from the top managers of [the general director's] plant, the only formal authority over his enterprise was a distant state bureaucracy that was spinning out of control, and the now independent, authoritarian [general director] could do what he pleased. [The general director] was probably tempted to treat the company as his personal property. This process has been called spontaneous privatization. BLASI, supra note *, at 33.

85 BLASI, supra note *, at 40.

86 BLASI, supra note *, at 40.

87 WDR, supra note *, at 55; BLASI, supra note *, at 192 (Table 3) (discussing slight discrepancies in number of firms privatized and citing sources).

88 Roman Frydman, Katharina Pistor \& Andrzej Rapaczynski, Investing in InsiderDominated Firms: A Study of Russian Voucher Privatization Funds, in 1 CORPORATE 
firms employed over 17 million workers and managers and included the bulk of the Russian industrial core, ${ }^{89}$ except for a few categories of firms, including energy, defense, and infrastructure. ${ }^{90}$ By 1996, when the big wave of privatization was over, 77.2 percent of medium and large state enterprises were privatized accounting for 88.3 percent of industrial output. $^{91}$

At the time of privatization, most issuers chose an option whereby a majority of their shares went to three groups of insiders: issuer management, the issuer labor force, and regional governmental agencies. The government decision to give firms this option involved following the path of least political resistance, giving a continuing stake to each group that had significant power running the firm prior to privatization. Although the mass privatization used vouchers and formally created open stock ownership, the program "was basically a management-employee buyout program because of its preferential treatment of managers and workers." 92 After insiders bought shares, each citizen could bid for some of the remaining shares at auctions using vouchers they were given. Immediately after privatization, insiders undertook additional share purchases on the open market and typically ended up owning about twothirds of the shares of firms. On average, managers owned 9 percent and workers about 56 percent. ${ }^{93}$ Outsiders used vouchers to buy about 20 to 30 percent, split between investment funds and individual investors. The government retained the remainder of shares, and even more importantly,

GOVERnANCE IN CENTRAL EUROPE AND RUSSIA 189 (Roman Frydman, Cheryl Gray \& Andrzej Rapaczynski, eds., 1996).

89 In 1988, medium (more than 200 employees) and large enterprises (more than 1000) accounted for about 95 percent of employees and production in Russia. BLASI, supra note *, at 25 .

In 1995 a few large, rich firms such as oil and gas companies, were privatized through a controversial "loan for shares" program that handed shares over to a number of financial-industrial groups controlled by new private tycoons.

91 BLASI, supra note *, at 25. The totals now are higher: 4600 mainly small and medium enterprises underwent some form of privatization in 1996. Transition Indicators for the Russian Federation, EBRD TRANSITION REPORT, Nov. 3, 1997, at 195 available in Nexis Library, Curnws File.

92 WDR, supra note *, at 5. Insiders had several privatization options. About one quarter of enterprises chose option 1 , which gave minority employee ownership for free. About three quarters of firms chose option 2, which allowed managers and workers to acquire 51 percent of the firm for extremely low prices (and therefore take formal control of the firm). A third option attracted only 2 percent. This option allowed a management buyout on the promise of reaching particular restructuring targets. BLASI, supra note *, at 41.

93 WDR, supra note * at 55, Frydman, et. al, supra note * at 189. 
it often retained control of the land on which enterprises are located. ${ }^{94}$

Post-privatization, senior managers used numerous mechanisms to thwart the power of employees and outsiders and to maintain control. These mechanisms included, for example, keeping share registries locked up in their offices and refusing to acknowledge ownership by people they disfavored, threatening to fire workers who sold shares to outsiders, and stock dilutions aimed at reducing the power (as well as the financial claims noted earlier) of outsider shareholders. ${ }^{95}$ They also provided little or no disclosure about the business operations or finances of their firms. Even voucher investment funds, which are the most aggressive and informed outside shareholders, often cannot get rudimentary information about the firms in which they hold shares and instead "resort to spying on their own companies." 96 Thus, managers did not acquire a majority of shares during the initial privatization, but they locked up nearly unshakeable control. ${ }^{97}$ Workers, who did acquire majority shareownership, did not achieve anything like a "workers democracy." Instead, they remained locked in an uneasy arrangement with management, often able to block restructuring but not able to seize control. Among the many reasons for continued employment of redundant labor, managers sometimes kept employees to prevent them

94 Paul Funder Larsen, Buying Land is Next Hurdle for Private Firms, Moscow TIMES, Nov. 26, 1996 ("Many companies seeking to get a clearer title to their land still face stiff resistance from regional authorities who see land ownership as a source of power in dealing with local enterprises."). This is reported to be a declining problem in the big cities but is still serious in the rest of the country.

95 Carole Landry, Russia's Communist Bosses Are On The Way Out, AgENCE FranCE PRESSE, Dec. 15, 1994 (“' Old guard managers, who supported privatization in exchange for assurances that they would keep their jobs and full array of perks are desperately fighting back. Some managers physically threaten challengers at shareholder meetings, rig shareholder votes or illegally change corporate charters,' [Andrei] Shleifer and [Dmitry] Vasilyev said.”); Peter Galuszka \& Patricia Kranz, Look Who's Making a Revolution: Shareholders, BUSINESS WEEK, Feb. 20, 1995 ("new tricks . . range from diluting the ownership stake of investors to such simple ploys as erasing the names of outside investors from computerized shareholder lists").

96 Frydman, et. al, supra note * at 204.

97 A reporter notes:

Most Russian enterprises are still run by red directors - former communists who stack their boards with old-regime subordinates or cronies, bully workers into selling their shares back to management, and deny outside shareholders access to their books, boardrooms, and shop floors. Many consolidate control of their companies by issuing large blocks of new shares to company insiders, often at bargain basement prices.

Patricia Kranz, Shareholders at the Gate, BusINESS WEEK, June 2, 1997, at 60. 
from selling shares to outsiders. ${ }^{98}$ If managers fired workers, they could no longer use the threat of job loss to deter share sales.

c. The Persistent Pattern of Initial Privatization. - The effects of the initial privatization are persistent. Insider ownership is declining slightly: dropping from 65 percent in 1993 to about 56 percent in 1995, ${ }^{99}$ but the problems of majority insider ownership remain endemic. By 1996, the typical board contained four managers, one state representative, and two outside shareholders. ${ }^{100}$ Because five directors were required to make decisions, the insiders and the state representative could always prevail, if they cooperated. ${ }^{101}$

The 1996 corporate law was intended to respond precisely to the problem of insider domination that emerged from the initial privatization scheme and immediate post-privatization enterprise behavior. ${ }^{102}$ For example, the new corporate law attempted to improve the position of minority outside shareholders by mandating cumulative voting. As a result, outside owners of share blocks are increasingly able to get themselves elected to the board of directors, despite resistance by insiders to the cumulative voting rule. In turn, Roman Frydman \& Andrzej Rapaczynski show that outsider representation on the board has had some positive effect on firm performance. ${ }^{103}$ Also, significant transactions in which insiders are interested are supposed to be approved by the outside shareholders. Nevertheless, insiders have found numerous mechanisms to circumvent the protections apparently offered by the 1996 reforms and effect non pro-rate distributions. ${ }^{104}$

98 "If [directors] see outside shareholders trying to get hold of their company, these managers often shout down their proposals at meetings, intimidate employees who side with them and hold tight to the board - which is often still considered a Soviet-era workers' council. ... . Most employee shareholders, . . . are still passive and exert little influence over corporate governance because they are underrepresented on company boards." Natasha Mileusnic, The Great Boardroom Revolution, MOSCOW TIMES, July 16, 1996.

99 WDR, supra note *, at 55 .

100 BLASI, supra note *, at 99.

101 BLASI, supra note *, at 99.

102 See Bernard Black \& Reinier Kraakman, A Self_Enforcing Model of Corporate Law, 109 HARV. L. REV. 1911 (1996); BLASI, supra note *, at 98.

103 Roman Frydman \& Andrzej Rapaczynski, [cite].

104 While amendments keep being introduced to close loopholes, they do not appear to be effective. Katy Daigle, Bill Improves Shareholder Rights in Russia, MOSCOW TIMES, July 14, 1998:

[C]ritics said the legislation fails to attack the real problem - insider dealing and doubt anything but better information disclosure requirements and an 
d. The Enduring Cost of Insider Ownership. - To summarize, we observe three interrelated failures in Russia that are associated with the initial structure of insider ownership and control. First, the three groups of insiders have been unable to work together to operate their firms in a way that would maximize even their own joint benefit. They have tended to view their shares more as control rights than as financial instruments. Each group has, despite privatization, continued to focus primarily on how its firm could be run in a way that would most benefit it directly. Management extracts extensive perquisites and sweetheart business deals for themselves and associates. Labor ensures continued employment of redundant workers. Regional government entities continue receiving public services for the community. ${ }^{105}$ Each group goes along to get along; they agree to meet each other's minimal demands in exchange for getting a share. But these insider deals ignore the cumulative effects on the value of the firm for themselves and for outsider shareholders. ${ }^{106}$ One Russian fund manager notes: "The majority of directors still fear loss of control to an outside investor and have not yet recognized that a smaller piece of a growing pie is more

understanding of basic ethics will help the situation. In Russia, company directors and managers are routinely accused of insider dealing, which includes everything from accepting bribes to acting against their company's interests to selling assets or shares to relatives or friends.

Id. Insider dealing is not limited to management, but also includes deals in favor of local governments and labor. See, e.g., Stephanie Baker-Said, Watchdog Gives Not to MGTS Floatation, Moscow TIMES, Apr. 22, 1998 ("Moscow City Telephone Network, or MGTS, is planning to increase its authorized capital by 50 percent, handing the shares over to a single shareholder linked to the Moscow city government for next to nothing.").

105 For example, in Moscow, "This cozy relationship is multiplied a thousand times. According to many business people, [Moscow Mayor] Luzhkov used property as leverage. The property was leased for a nominal sum, but the city also made unwritten demands not in the lease: to plant trees, rebuild a hospital, pave a highway." David Hoffman, The Man Who Rebuilt Moscow: Capitalist Style Could Propel Mayor to National Power, WASH. Post, Feb. 24, 1997, at A1.

106

One reporter notes:

The reluctance of many directors to use the stock market for their benefit is a paradox: After all, an overwhelming majority of directors managed to grab sizeable portions of equity in their companies during the wild privatization years of 1993 and 1994, usually by buying out swathes of shares with the help of cheap bank loans through a highly abused process known as closed subscription. Were directors to understand the virtue of shareholder value, they could help make themselves even richer.

Gary Peach, 1997 an Outstanding Year Despite Market Nervousness, Moscow TIMES, Jan. 131998 
valuable than ownership of a dead enterprise."107

Second, the three groups run the firm in a way that is particularly disadvantageous to outsider shareholders. ${ }^{108}$ The primitive state of the Russian legal system and the general lack of corporate transparency means that outside shareholders gain no real protection from the fiduciary duties nominally placed on managers and only weak protection from procedural rules designed to police interested transactions. Majority insiders can usually crush what would otherwise be the only meaningful constraints on their behavior: the ability of outsiders to vote out the board and the hostile takeover threat. ${ }^{109}$

And third, the above failures inside existing firms in turn limit capital market development, with collateral consequences for both existing and new firms. Established firms cannot raise new capital through the public sale of new equity; a particularly grave problem given the primitive state of banking in Russia. Also, the resulting lack of vibrancy in the secondary market for insider shares means that primary and secondary markets do not develop for the shares of new, post privatization firms. ${ }^{110}$ This lack of stock market vibrancy also slows outsider purchases of employee shares and delays the resulting conversion of firms with majority insider ownership to majority outsider ownership. The result of these three failures has been an overall lack of

107 Neither CEOs Nor Red Directors, The Managers of Russia's Privatized Industrial Firms, RUSSIA EXPRESS BRIEFING, Dec. 9, 1996.

108 Commenting on the aluminum smelting industry, one reporter suggests that, Since they aren't now looking to attract capital through share issues, the companies' directors are not concerned about plummeting stock prices, and don't really care what the market thinks about them. Aluminum shares last traded actively in 1994 and 1995, when various insiders were trying to establish control of smelters during the privatization process.

Mark Whitehouse, The Other Side of the Room, Moscow Times, Sept. 16, 1997.

109 According to the EBRD Transition Report:

In over $65 \%$ of Russia's 18,000 privatized medium-sized and large firms, management and employees have majority ownership, whereas non-state outsiders control only $20 \%$ of these companies. While in the top 100 largest companies outsiders have an ownership stake well above the average, the wide dispersion of these shareholdings often ensures a controlling position for the management. Insiders typically focus more on maintaining control over their Id. firms than on restructuring.

110 "The main source of the expansion of the private sector remains the privatisation process and the contraction of the state sector. . . The creation of de novo businesses continues to lag far behind the pace typical for the central European countries and many newly established businesses continue to operate in the informal economy." EBRD Transition Report. 
needed restructuring. ${ }^{111}$

\section{B. How Initial Conditions Cause Corporate Governance Failures}

This section establishes the causal links between the initial conditions just described, the corporate governance failures detailed in Part I, and the resulting harms to the Russian economy.

1. Peculiar Firm Boundaries and the Failure to Maximize Residuals . - Poorly defined boundaries render firms with weakly constrained and incentivized management particularly susceptible to several of the five non residual maximization pathologies. To start, consider Pathology 1: continued operation of a value-destroying firm. From the moment of privatization, Russia had many such firms that should have been instantly shut down. Because of their peculiar boundaries, these still-born firms made little sense as a way to match location, assets, workers and product mix - but they often had assets with significant salvage value, urban land in particular. Despite the damage they cause to social welfare, managers of such firms indulge their personal preferences by continuing firm operations. When land is the salvageable asset, managers can easily avoid taking the residual maximizing decision, because Russia does not have a well-developed land market, and so there is no effective way make salient the opportunity costs of using the land for continued firm operation.

A similar story can be told with respect to Pathology 2, where potentially viable firms fail to use existing capacity efficiently. Most Russian firms not displaying Pathology 1 have a strong potential for displaying this second one. Cost minimization is a necessary condition for residual maximization. By definition, what made these firms borders peculiar was the fact that they were not transaction cost minimizing, so by definition, firms in this second category require major restructuring.

111 According to the EBRD Transition Report:

Enterprise restructuring has hitherto been achieved mainly through changes in the product mix, shedding of labour through attrition, expanded use of unpaid leave or reduced hours. Deeper restructuring in the form of factory shutdowns, changes in management, major reorganisations and modernisation is at a very early stage and is constrained by, among other factors, limited access to investment resources. Recent evidence suggests that roughly $25 \%$ of the medium-sized and large companies are engaged in serious restructuring, many of them being members of Financial and Industrial Groups (FIGs). About half of the medium-sized and large companies have not as yet undertaken any meaningful restructuring.

Id. 
Unlike managers of firms in the first category, it is not self evident why loosely constrained managers of these firms would avoid restructuring and operate their firm in a non-residual maximizing way. However, the story told below of bargaining failures among the insider groups suggests that, in a large number of cases, managers may have reason to avoid restructuring, thus dooming their firms to long-term display of Pathology 2.

The peculiar borders of Russian firms have also made them more prone to Pathology 3. This pathology is more likely to occur with an enterprise encompassing an unnecessarily large number of different activities: if the cash flow from one activity is sufficiently great that it exceeds the positive net present value projects arising out of that activity, then the managers are likely to invest the surplus in negative net present value projects associated with other firm activities. If the two activities were split into different firms, the cash flow would more likely be paid out as dividends and investors would have the chance to fund projects with more promising returns.

Finally, compared with outside investors facing a fragmented set of single purpose firms, the management of an enterprise encompassing an unnecessarily large number of activities will - because of their distance from the idea sources and the rigidity of internal communications channels - also likely have more difficulty identifying positive net value projects. Thus the peculiar boundaries of Russian firm also aggravated the effects of Pathology 4.

2. Insider Dominance and the Failure to Maximize Residuals .

a. The Nature of the Failure and the Need for a Credible Promise. - After privatization, most Russian firms were majority owned by three groups of insiders: management, employees and regional governmental authorities. At first glance, this ownership pattern would appear to offer many advantages and solve several firm-level problems. Management's large stake, typically over $20 \%$ of what are often very large enterprises, should have led to a substantial identification with the interests of shareholders, while not being so large as to provide an insuperable barrier to takeover. ${ }^{112}$ The stake of employees should have substantially helped some of the contracting problems associated with long-term employment relationships - such as encouraging asset specific

\footnotetext{
112 Irrationality may be a problem here too. In one odd report, "one company director . .. owned over 51 percent of a company, ... yet took personal bribes of about $\$ 10,000$ to push through decisions that robbed the company of millions. Obviously, this man doesn't understand what he's doing." Katy Daigle, Bill Improves Shareholder Rights in Russia, Moscow TIMES, July 14, 1998.
} 
human capital investments by employees - and should have significantly reduced resistance to needed downsizing (by offering implicit compensation through increased share value). More importantly, when the stakes of the three groups were taken together, they typically had a right to receive seventy percent or more of the residuals. Thus they had huge incentives to agree that the firm itself should be operated in a fashion that maximizes these residuals. Yet, as we will see, the structure of ownership and control has actually worked in the opposite direction, contributing to the failure to maximize residuals.

Traditionally, the choice between public and private ownership has been seen as involving a tradeoff. Public ownership leads to a lower cost of capital because the firm's shares can be sold for a higher price due to their liquidity and capacity to be part of a diversified portfolio. Public ownership also permits a degree of outside monitoring. ${ }^{113}$ Private ownership, however, greatly reduces the substantial residual reducing agency costs of management that are associated with public firms.

At first glance, Russian firms have an ownership structure that would appear to come close to that of a private firm and hence they should do well at maximizing their residuals. A large portion of the shares not owned by management are owned by just two other entities the workers and government. This, one should expect, would radically reduce the transaction costs and collective action problems associated with shareholder monitoring and action that plague the public firm. But Russian firms are falling far short of maximizing their residuals, suggesting that they are suffering instead from the worst of both worlds. They do not seem to be getting the benefits of a private ownership structure. Yet, the existence of insider control combined with weak corporate law makes raising capital by public sale of equity impractical and so they are not receiving the traditional benefits of public ownership either.

The three groups of insiders appear to have been unable to work together to operate their firms in a way that would come close to maximizing their own joint benefit. Their actions suggest that they continue view their shares more as control rights than as financial instruments. Therefore, each group has, despite privatization, continued to focus primarily on how each firm could be run in a way that would most benefit it directly. Managers make sweetheart business deals for themselves and their associates; labor insists on continued employment of redundant workers; regional government entities demand that firms

113 See, for example, Brent Homstrom \& Jean Tirole, Market Liquidity and Performance Monitoring, 101 J. POL. ECON. 678 (1993). 
provide public services even though the firms are rarely the least cost providers. These behaviors are major deviations from the decisions that would maximize the firm's residuals. By failing to cooperate through good corporate governance, the insiders fail to capture the potentially large financial value of their shares. The aggregate benefit to these three groups from these deviations is less than the resulting diminution in the residuals. Management's gain from the sweetheart contracts is less than the price improvement or other advantages of using the suppliers and purchasers chosen on an arm's length basis. Labor's gain from wages and benefits superior to whatever redundant workers could obtain in alternative employment is less than the reduced residuals enjoyed by the firm as result of their continued employment. Government's savings from not having to pay other suppliers of services is less than the cost to the firm of providing these services, which would be outside the boundaries of the firm if it were operated in a transaction cost minimizing fashion.

Explaining why insiders do not agree to maximize the firm's residuals as part of an obvious Coasian bargain starts with the observation that there is a difference between when insiders receive benefits from their shareholdings under existing arrangements and when they would receive their benefits under any kind of bargain to run the firm to maximize its residuals. Under the current arrangement, the insiders receive their benefits immediately, as they are generated by the firm's ongoing operation. Under a residual maximizing bargain, they would receive them later, in the form of shareholder distributions. ${ }^{114}$ This delay is significant: a deal is not possible unless management is able to make a credible promise that it will live up to its end of the bargain. Otherwise labor and local government would be put in a position of having to give up their benefits now without an assurance that

\footnotetext{
114 The reader may raise two questions here. The first is that the failure of insiders to come to these deals may be intimately related to the delay because the insiders may have very high rates of time discount and hence receiving benefits now is preferred to receiving larger benefits later. The answer to this, however, is that the Coasian bargain that we are contemplating already takes such discounts into account. Efficient operation of the firm contemplates that the residuals be discounted to present value.

The second question concerns whether an insider could avoid the delay problem by selling its shares to others. But this does not make the problems associated with delay go away, the buyer instead must suffer them. If delay also implies uncertainty as to whether the gain will ever in fact be received, the buyer will pay commensurately less for the shares, in this regard, the insider is just as badly off as if he had held onto the shares.
} 
management, which runs the corporation day to day, would live up to its end of the bargain: giving up its particular special benefits and subsequently distributing the gains from the overall deal as dividends.

b. The Difficulty in Making the Promise Credible. - Under current conditions in Russia, management would find it almost impossible to make credible a promise to live up to its end of the bargain.

$i$. Legal enforcement. One way that a promise can be credible is if the promisee can easily and economically use the courts to gain the promisor's compliance or obtain damages. For a number of reasons, labor and local government are unlikely to be able to do so. The first step in a promise being made credible through the availability of court enforcement is the existence of a legal obligation on the part of the promisor. As a formal matter, Russian managers may be bound to maximize residuals and distribute them pro-rata even without an explicit deal with other insiders, but this is not clear as a matter of law. The Russian corporate code nominally imposes on the management of joint stock companies the obligation to act in the interests of the company reasonably and in good faith. ${ }^{115}$ The language of this obligation is similar to the statutory provisions for fiduciary duties under U.S. corporate law, ${ }^{116}$ which are interpreted as banning extensive perquisites and prohibiting transactions between the corporation and management or its associates unless the transactions offer the firm terms as good as can be obtained in an arm's length deal. ${ }^{117}$ There is essentially no judicial gloss, however, to affirm that this language would be interpreted in the same way in Russia.

The second step is the actual availability of court enforcement. Russian law again nominally provides for a form of derivative suit for damages in the event of a breach of management's statutorily imposed obligations. ${ }^{118}$ Even if we assume that as a formal matter management is obliged to behave in the fashion contemplated by the Coasian bargain hypothesized here, labor and local government are unlikely to be able to use the courts to stop violations of that obligation, however. According to Bernard Black and Reinier Kraakman, "In Russia ... courts function

115 Federal Law on Joint Stock Companies, of December 26, 1995, (hereinafter FLJSC) Article 71(1).

116 See, for example, Revised Model Business Corporation Act Sec. 8.30.

117 See William CARY AND MELVIn EISENBERG, CORPORATIONS CASES AND MATERIALS, 647-809 (7th ed. 1995).

118 See FLJSC Article 71(2) and Article 71(5). It is not clear that injunctive relief, whereby a court invalidates such transactions or orders they not be undertaken, is even available to shareholders as a formal matter. 
slowly if at all, some judges are corrupt, and many are Soviet-era holdovers who neither understand business nor care to learn. Better judges and courts will emerge only over several decades, as the old judges die or retire." 119

Another possible way of gaining managerial compliance while relying less on the court system is through legal regulation of the corporation's own process of transaction authorization. Russian law has procedural rules designed to make less likely the authorization of transactions in which management or a major shareholder is interested and that are disadvantageous to the corporation. These rules require that such transactions be approved by the vote of a majority of those directors who are not interested in the transaction or, in certain cases, by a disinterested majority share vote. ${ }^{120}$ Special procedural rules apply also to the approval of very large transactions. The theory is that these rules require much less court intervention to be effective because the factual determination of whether or not there has been compliance is sufficiently simple and clear as to make the rules nearly "self-enforcing." In the end these rules too may not be much help, however. ${ }^{121}$ To show that management or a major shareholder is interested in a transaction requires proving that it is associated in some specified way with the other party to the transaction. A general lack of transparency concerning who owns the shares of, or has managerial positions in, the corporations involved makes this proof difficult. ${ }^{122}$ Even when this is accomplished, it is hard to know whether the pattern of votes cast in fact conform with the procedural requirements, in part because of these same transparency problems and in part because of difficulties in determining who voted which way. ${ }^{123}$

\footnotetext{
119 Black \& Kraakman, supra note *, at 1914.

121 Black \& Kraakman, supra note *, at 1915-1917.
}

122 In theory, such persons, pursuant to FLJSC Article 82, are required to disclose this information to the company's board, inspector and auditors. There is no obvious incentive for such persons to comply with this provision, however. Even if they do, it is not clear that the information would become available to anyone who possessing it might act to challenge the transaction for lack of compliance with the approval procedures. It was the experience of the authors, in connection with an interested transaction involving one of Russia's largest oil companies, that this information was not available, either because the insiders did not comply with Article 82 or because the company did not make the information public.

123 It was also the experience of the authors in connection with an interested transaction involving one of Russia's largest oil companies that the public records of the directors meeting and the shareholder's meeting at which the transaction was approved 
ii. Reputation. Another way that a promise can be credible is where the promisor has a prior reputation for keeping its promises in situations in which legal enforcement is difficult and the non-legal consequences - other than damage to reputation - would not have been expected to be great. Such a promisor is unlikely to breach the promise in question because doing so debases its reputation, which is costly. The problem in Russia is that in the few years since privatization the management of the typical corporation has not had the time to develop such a reputation, at least with respect to promises of this magnitude.

While the same management team may have been in place for a significant time prior to privatization, the team, and all those it dealt with, were subject to strict ministerial supervision. Because of this, the need for promises was less and the non reputation-related negative consequences of breaching the promises that were made was greater. Adding to these negative consequences was the fact that most promises were made with persons where there was an ongoing course of dealing.

An additional problem here is that the promise that management needs to make runs contrary to the norm for managerial behavior in Russia. A person who makes a particular promise that he has not made before, but where the behavior promised is the norm, is likely to be credible if over time she has fulfilled other promises that conform to the norm with respect to other kinds of behavior. Such a person is viewed as a "regular fellow" or a "straight shooter." Where the behavior promised runs contrary to the norm, such a reputation is of no help.

iii. Hostages. A third way a promise can be made credible is where the promisor gives the promisee a "hostage" that can be taken by the promisee if the promisee feels that there has been a breach. The ideal hostage is something that is worth much less to the promisee than the promisor. A firm's plant might serve this kind of hostage function if it were vulnerable to certain kinds of labor actions, for example a sit-in. Labor is poorly organized in Russia, however, and so collective action problems make it unlikely that it would be able to use the plant in this fashion. Such actions also would likely be repressed by governmental authorities. Any promise by management to waive its rights to such governmental assistance would have its own credibility problems.

$i v$. The need for ex post verification. None of these ways of making a promise credible will work unless there is some method of ascertaining whether the promise has been kept or not. This is another serious obstacle to the parties making their Coasian bargain requiring management to use its control to maximize residuals and then distribute 
them pro-rata. In terms of ex post verification, management is in the same position making this promise to labor and government as it would be making this promise to any non-control outside shareholder. The whole apparatus of modern auditing and accounts is designed to provide a reasonable assessment of the amount of residuals that have been generated, to identify the amount of spending for management compensation and perquisites, to ferret out corporate transactions in which management is interested, to identify which investors receive how much in distributions, and to highlight outright theft. Application of this apparatus to Russian corporations is in its infancy and so most remain far from transparent. ${ }^{124}$

c. The Lack of Strong Capital Markets. - Along with the inability of management to make credible promises, the absence of strong capital markets (itself a result of widespread corporate governance failures) frustrates the parties making a Coasian deal to maximize residuals. Even if workers were able to obtain what they believe to be a credible promise from management, they would have great difficulty selling for cash today their rights to receive in the future the benefits of the deal. This is an important additional complication since the desperate living conditions of many Russian workers, combined with a belief that the future could not be worse and might be better, may give them a strong positive time preference - an illustration of the difficulty of making social welfare evaluations of decisions involving the allocation of resources over time when capital markets fail. If discounting to present value is done at the interest rate implied by the strong positive time preference of highly credit constrained workers, managers of Russian firms may be running them in ways that suddenly appear far more efficient.

d. Applicability to Different Pathologies. Understanding the bargaining dynamics among competing inside owners of privatized Russian firms helps explain the widespread incidence in Russia of

124 For example, consider the following account:

A barrier to action by outsiders is the information vacuum that prevails in many insider-held firms. They all try to look poor. The only real books are in the director's safe, or his head. It's hard even to know which firms are worth taking over. Once a successful bid is made, one Russian consultant described the takeover itself in virtually military terms: Advance spies must learn what safes and computers hold the key files. On takeover day, armed guards must secure all of these within minutes or the data, and the cash behind them, will simply vanish. All physical assets must be nailed down or nothing will be left but an empty shell. These are little details foreign investors don't always understand, noted the consultant.

Edwin Dolan, Resisting Shock of New, MosCOw TIMES, Apr. 8, 1997. 
Pathologies 2 and 3, the failure to use existing capacity efficiently and the misinvestment of internally generated cash flows. The preference of labor shareholders to retain redundant workers rather than maximize residuals leads directly to Pathology 2. There are two ways that the firm can keep employment high in the short run. One is to produce more output than would be called for if the firm set marginal cost equal to marginal revenue. The other is to produce this level of output using a combination of inputs that includes more labor than would the cost minimizing input combination. Both decisions involve failures to use existing capacity as efficiently as possible and both reduce residuals as a consequence. The labor shareholders' desire to retain redundant workers also leads to Pathology 3. While firm investment in negative net present value projects is not necessary for employment to be maximized in the current period, it is for employment to be maximized in the future (assuming that the new investment does not embody a radically laborsaving new technology). This is true whether the investment replaces worn out existing capacity or represents an actual expansion of capacity. Labor's interest here parallels managers' personal interests in running as large an enterprise as possible, everything else being equal.

The bargaining dynamics story is not as helpful in explaining Pathology 1. The residual maximizing change necessary for firms displaying Pathology 1 is to close them immediately. As we have seen in Part I, to the extent that an unreformable value destroying firm continues operating because of corporate governance problems, it is because the firm has cash reserves (unlikely in Russia) or salvageable assets. The Coasian deal here would be to close the firm as soon as these assets could be sold. There is no time delay requiring a credible promise on the part of management, and hence none of the problems discussed above should block the deal.

How then can the existence of firms displaying Pathology 1 be explained? One possibility is that such firms do not exist, that we have created a category with an empty set. The anecdotal evidence presented here, however, suggests that this is not the case. Another possibility is that title to these salvageable assets, at least in the case of land, is not as clear as we have portrayed it, in particular that local authorities have the power to block land sales independent of the powers they have as shareholders. ${ }^{125}$ If so, the needed reform is in property law and public law, not improved corporate governance. Yet another possibility is that the market for such salvageable assets is extremely illiquid due to severe

125 Paul Funder Larsen, Buying Land is Next Hurdle for Private Firms, Moscow TIMES, Nov. 26, 1996. 
limitations in capital markets generally in Russia. Thus existing Pathology 1 firms will gradually be shut down as buyers are found who will pay full value for the assets, but that the process will take considerable time. If that is the case, the initial conditions explain the problem not by their direct effects on the Pathology 1 firms, but by their contribution to the failure of corporate governance in Russia generally with that failure's attendant deadening of Russian capital markets. Finally, Pathology 1 firm Coasian deals may not be made because of perceptual problems on the part of labor. Labor may believe that the redundant jobs they wish to save are worth more to them than is really the case. The shareholder distribution that labor would receive upon sale of the salvageable asset would then not seem to labor to be worth the loss of these jobs. If this is the case, however, it would form an additional (or alternative) explanation for the failure of the Coasian bargain in the cases of firms displaying Pathologies 2 and 3 as well.

The failed Coasian bargain story also does not explain very well Pathologies 4 and 5. These pathologies involve failures of suitability and capability, not conscious decisions by mangers to put their personal interests above that of firm residual maximization. In essence, managers of firms displaying these pathologies are doing as well as they can, but a firm with less risk averse or more imaginative managers could do better. The problem is thus not the result of competing insiders unable to make a Coasian bargain. The social welfare effects of these failures would be corrected either by replacing the incumbent managers or by assuring that there are other venues for implementing the positive net present value projects being rejected or unrecognized by these managers. The failings here are in the market for corporate control and the market to provide capital for new firms. Thus again, the initial conditions help explain the Pathologies 4 and 5 not directly, but by their contribution to the failure of corporate governance in Russia generally and the attendant deadening of Russian capital markets.

3. Insider Dominance and Non Pro-Rata Distributions .- Initial conditions in the form of insider dominance also can help explain the massive failure of Russian firms to distribute their residuals pro-rata to their investor owners. The primitive state of the Russian legal system and the general lack of corporate transparency means that outside shareholders gain no real protection from the fiduciary duties nominally placed on managers and only weak protection from procedural rules designed to police interested transactions. Privatization, as we have seen, resulted in most firms having the insiders in the majority. This crushes what would otherwise be the only remaining meaningful 
constraints on these insiders' behavior: the ability of outsiders to vote out the board and the hostile takeover threat.

Initial conditions also play a role, though more indirectly, in the non pro-rata distributions by firms where the insiders have less than a majority of shares but managers still control the firm. In theory, these managers would at least be subject to being thrown out by the vote of the majority outsiders or as a result of a hostile tender offer. Shareholder votes have huge collective action problems associated with them, however, and as for hostile tender offers, the same story applies here as discussed just above. The initial conditions, by their effect on corporate governance among Russian firms generally, have done severe damage to the creation of vital capital markets generally. Thus no effective market for corporate control has developed and the hostile takeover check against non pro-rata distributions by majority outsider owned firms is really a chimera.

It is worth considering the other causal factors of non pro-rata distributions as well, and here the governance failure typology is quite useful. For example, of all the pathologies, Pathology 6, diversion of claims, is perhaps most amenable to traditional law reform efforts, at least in some of the pathology's forms. Perhaps registering transfers of shares could be centralized in a public or quasi-public institution rather than left to the whims of individual firm managers. Particular loopholes in the corporate law, such as those regarding convertible bonds, can be tightened; standards of review in bankruptcies can be adjusted. But even here, when so much is at stake, insiders may be able to invent ever more subtle diversion mechanisms. For example, many of the procedural protections available to shareholders depend on identifying outside disinterested owners, and requiring a majority of their votes for important changes in corporate structure. Recent proposals attempt to strengthen these key protections. ${ }^{126}$ But insiders have proven adept at obscuring the identity of owners and evading these procedural protections with ostensibly outside owners actually controlled by insiders.

Pathology 7, diversion of assets, is not as amenable to simple law reform efforts, even assuming that it became easier for shareholders to obtain judgments and enforce them. Even the Delaware Chancery, presumably the most sophisticated court in the world for detecting breaches of the duty of loyalty, has a difficult time separating out

126 Jeanne Whalen, FSC's Vasiliyev Soldiers On Amid Dismissal Rumors, Moscow TIMES, Dec. 5, 1998 (noting proposed "amendments to close loopholes in the Law on Joint Stock Companies and a draft Law on Affiliated Persons that would closely regulate the actions of majority shareholders."). 
management decisions that are legitimately taken to increase residuals but have the incidental effect of disproportionately benefitting insiders, from management decisions primarily motivated by a management desire to effect a non pro-rata distribution. It will be a long time before Russian courts are likely to achieve Delaware's level of competence. As for the more blatant examples of non pro-rata distributions, they are usually criminal and implicate a broad array of institutional and legal deficiencies in Russia. These deficiencies include the refusal of local officials to recognize, in their role as enforcers of property rights, decisions of legitimate corporate processes when these decisions run contrary to the desires of incumbent managers.

\section{Trends in Corporate Control}

1. Dynamics of Initial Ownership Patterns. - The original allocation of shares at the time of privatization is not a sustainable ownership pattern over time. Many firms have already been taken over completely by one group of insiders, usually the managers, who purchase the shares of the other insiders. This is a predictable result because the multiple groups of insiders are unable to make joint wealth maximizing agreements. When managers take complete control, they can operate the corporate assets more as if the assets were their sole private property. This is a more stable ownership pattern and it represents a social gain because the managers are more motivated to put assets to their first best uses.

The management control equilibrium is still far from ideal, however, and its shortcomings represent large continued failings in the Russian system of corporate governance. First, the deals necessary to buy out the other insiders are not easy to make because management itself has no ready access to capital. Often their aims are achieved by extra-legal means. Thus, the new equilibrium will take considerable time to reach and often does not put assets, at least immediately after the ownership restructuring, in the hands of the persons most capable of using them. The stakes are especially big because these assets include control over cash flows that the managers often cannot invest sensibly within their own firms, but capital market failures mean cash flows are denied to other entrepreneurs who could make better use of them. These failures, as we have seen, stem from the continued ability of insiders to divert wealth from any remaining outside shareholders, which makes raising capital through public sales of equity by any firm virtually impossible. Given the paucity of other sources of capital, many 
promising investment opportunities go unfunded. Moreover, the absence of outside investor voice in the affairs of the firm may mean that it is not efficiently run even to the extent that doing so is now in the best interests of the management insiders. These managers are often still holdovers from the communist era and would be able to act more in their own and society's best interests if prodded by more market-oriented outsiders, but their continued desire to engage in non pro-rata distribution makes such consciousness-raising advice inadvisable to obtain.

Early empirical work suggests that the best improvement in corporate performance in Russia comes when firms have substantial outside ownership and those owners place outside directors on the board. ${ }^{127}$ This observation may be causally backward, in that outsiders tend to invest in the best firms, particularly those that are generating sufficient positive cash flow that payment of dividends becomes possible. The question is whether the privatized enterprises can systematically move in the direction of increasing outsider ownership and control. The analysis in the sections above, suggests cause for concern. When multiple insiders block each other, there is little commitment by insiders to the financial aspects of share ownership. Similarly, when manager insiders take control and divert assets illegally, outside investors have little incentive to purchase minority interests.

Privatization is intended to create wealth that is available for reinvestment in Russia, but the insider structure of corporate ownership may instead stimulate capital flight. Diversifying risk through portfolio investment in domestic firms is impossible. Domestic equity investments, to be worthwhile, must be in control amounts under the current system. A system that starts with fragmented insider ownership has led to one where public offerings are impossible and capital leaves Russia in part because of inadequate viable investment opportunities.

2. Evolution of Financial Industrial Groups . - For a short period, Russia seemed to be moving to a system of corporate control concentrated in huge, sprawling conglomerates that came to be known as financial-industrial groups (FIGs), organized around one of seven chief oligarchs, each with a captive bank, a holding company, and multiple

127 For example, consider Baltika Brewing. "Business has boomed thanks to a steady stream of foreign investment, effective marketing and a good management team." John Varoli, Baltika Plans to Boost Output 250\%, Moscow Times, April 22, 1999. The firm has been implementing a large capital investment program using its own reserves as financing, has secured outside credit, and has been one of the few firms in Russia to pay dividends. One element in the firm's success and credibility on international financial markets has been firm oversight by a Scandinavian brewing group that holds 70 percent of Baltika's shares. Id. 
privatized companies as subsidiaries. ${ }^{128}$ The most significant boon for the FIGs occurred in 1995 with the infamous "loans-for-shares" scheme in which the oligarchs gave relatively small loans to the government to plug the budget deficit and in exchange received as collateral security interests in shares of the most valuable Russian resource-extracting firms: oil, minerals, timber, and so on. When the government did not pay back the loans, the oligarchs conducted rigged auctions through which the collateral on the loans became controlling shareownership in these firms. ${ }^{129}$ One oligarch, Vladimir Potanin, in discussing the loanfor-shares program, noted, "It was bad. The prices were cheap. We can stop discussing this. It was bad. But it did solve the problem of having more efficient owners."130 According to one estimate, the chief oligarchs, through their FIGs, were said to control 40 percent of Russia's economy. The seven "grey cardinals,"131 however, rather than each working to improve the operations already under his particular control, fought each other to extend control to additional assets. This led George Soros to compare Russia to "a canoe in which seven men are fighting over a horde of gold [and] are too absorbed by this to recognize they are heading toward a waterfall." "132 The 1998 financial collapse set the FIGs back, bankrupting several of them, and so it is too early to see if they really put assets in the hands of more efficient owners. Initial indications are not promising, though. ${ }^{133}$

Early in the transition, optimistic commentators argued that the FIGs would roughly parallel the Japanese experience with keiretsu and Korea with the chaebol. Another analogy would be Oliver Williamson's M_form corporation, where the head office substitutes for the capital market's capital allocation and managerial monitoring functions. Given the extreme weakness of Russian capital markets, this substitution seemed a step forward. FIG oligarchs argued that they were relatively more productive than other sectors of the economy because their captive banks gave them access to funds at rates much lower than what was generally available, presumably because of reduced information

128 Timothy O'Brien, The Shrinking Oligarchs of Russia, NYT, Sept. 27, 1998, at C1; see also Patricia Kranz, Fall of an Oligarch, Business WeEK, Mar. 1, 1999, at 44 (listing the seven oligarchs).

129 David Fairlamb, Reining in the Oligarchs, InSTITUTIONAL INVESTOR, Nov. 1998, at 146.

130 O'Brien, supra note * (quoting Vladimir Potanin).

131 Fairlamb, supra note *.

132 Id. (quoting George Soros).

${ }^{133} I d$ 
asymmetries. And, echoing Williamson, they argued that "subsidiaries are overseen by group executives at the center, forcing local managers to pay attention to shareholder value, something that few other firms in Russia ever consider." 134 According to Mikhail Khodorkovsky, one of the oligarchs, "the FIGs are an excellent way of distributing scarce managerial resources throughout the economy. Surely, you can see that." 135

In practice, the keiretsu and chaebol were not the right analogy; rather the FIGs more closely resemble the old Soviet nomenklatura networks of former Communist and Komsomol members; ${ }^{136}$ FIGs "are to some extent a revival of the old (Soviet) branch ministries."137 They have not managed their enterprises under their control any better than firms generally have in the economy. Instead, oligarchs focused on non pro-rata distribution and generally continued to ignore problems of non residual maximization within the firms they controlled. According to one commentator, "The oligarchs were qualified to run banks only because of their familiarity with the corridors of power. Uneximbank [one of the FIG banks] never had any interest in improving manufacturing at any of its companies. It just wanted to channel money through the bank."138 So far, FIGs seem to have exhibited all the corporate governance pathologies we have already noted, they do not

134 Id.
135 Id. (quoting Khodorkovsky).
136 Poul Funder Larsen, 1996: The Year Big Business Became the State, Moscow
TIMES, Jan. 5, 1997.
137 Larsen, supra note * (quoting Anders Aslund).
138 O'Brien, supra note * (quoting Andrei Piontkovsky, director of the Center for Strategic Studies in Moscow). The usual routine was for the FIG banks to make loans to captive borrowers, and once those loans were disbursed, secretly to channel the funds directly into the banker's private offshore accounts. Id. "It would have been okay if these loans were made on an arms-length basis. But they weren't. When some banks made loans, they didn't specify interest rates or even when the loans had to be paid back." Id. (quoting a financial analyst). In short, "the oligarchs' idea of shareholder value is to asset-strip the companies they control and shunt the money offshore." Fairlamb, supra note *. Boris Nemtsov, a former deputy prime minister and key reform politician attributes the failure of reform generally to the role of the FIGs. He says,

The reason for this crisis is that after seven years of trying to build a market economy, we've ended up with oligarchic capitalism. It is characterized by the fact that a few FIGs, which, incidentally, work very inefficiently and are managed by greedy managers whose main aim is to pump money out of their enterprises and stockpile it aborad, produce the lion's share of GDP.

O’Brien, supra note * (quoting Nemstov). 
appear to be a step forward.

3. Some Reform "Thought Experiments" . - The critical problems we identify for Russian corporate governance lie at the intersection of uneconomic firm boundaries and control by competing groups of insiders. Poorly drawn firm boundaries exacerbate the corporate governance problems that arise when, as in Russia, managers are loosely constrained and poor incentivized. And control by competing groups of insiders confounds the usual prediction that insider dominated firms should be good at residual maximization, while it robs outsiders of their only mechanism for limiting non pro-rata distributions of residuals. For Russia at least, the firm borders at the time of initial privitization are "water over the dam" and all that can be hoped for now is greater development of a market for corporate assets. Voting rights, however, are something that can be altered by legal fiat, at least in theory. The Russian situation is demonstration of a case where the usual rationales for "one vote, one share" do not hold. It would be preferable if the voting rights of the competing corporate insiders could be sterilized in return perhaps for an even greater share of equity. Unless Russia undertakes such a reform, the best it can hope for is a slow and costly transition to a low-value equilibrium where outsiders are not available to provide public capital.

A primarily procedural approach to reform, which does not rely heavily on court enforcement, goes some way toward creating a viable corporate governance regime. ${ }^{139}$ However, we are skeptical that such reforms alone are going sufficiently to protect outsiders in a way that makes public equity finance possible - even after firms have made the transition to management control. Instead, as just suggested, we believe that the problems associated with insider blocks requires a more substantive approach that effectively disenfranchises the initial groups of insiders. For example, Bernard Black and Reinier Kraakman sensibly suggest neutralizing the voting rights of local governments which make up one of the competing blocks of insiders and which are unlikely to use their rights to maximize shareholder wealth. ${ }^{140}$ But, the suggestion to

139 See Bernard Black \& Reinier Kraakman, A Self_Enforcing Model of Corporate Law, 109 HARV. L. REV. 1911 (1996).

${ }^{140}$ Id. at 1971. They write,

Because we are skeptical about whether local officials will behave as responsible shareholders, we favor neutralizing government shares in the election of boards of directors: state bodies should neither nominate nor vote for candidates for the board of directors, although they should retain authority to vote on potentially company-transforming actions such as mergers and charter amendments. 
sterilize shares of local government owners applies with equal force to management and labor blocks. Rules allowing only outside shareholders to vote could also be used to take control of the board away from the initial group of insiders and increase the value of being an outside shareholder. Insiders with a reduced capacity to engage in non pro-rata distributions would focus more on the gains to be made from increased share value if residuals were maximized. Under such a reform, the shares would regain their vote when transferred to genuinely outside hands.

A grand political deal of insider vote sterilization in return for an even greater share of equity is obviously impractical in the environment of today's Russia in part because again, no one would trust the results. Policing the independence of outsider shareholders and setting up effective institutions to aggregate their votes is beyond Russian capabilities today. Nonetheless, over time, with the evolution of a somewhat more effective legal system and somewhat greater corporate transparency, insider vote sterilization might represent a way that would help Russia move toward a modern capitalist economy that could at least involve less reliance on these institutions than the bright line procedural approach that informs the current Russian code. Such a reform basically would involve taking the logic of those reforms one step further. Instead of partially disenfranchising insiders by requiring disinterested and super_majority votes for a wide range of corporate actions, insiders would be entirely disenfranchised. The entire focus of the corporate law system could then be on policing the single question of which supposedly outside shareholders are genuinely independent from management. The motives for parties entering the grand political deal would be the huge gains that better governed corporations could produce.

Another possibility along these lines - equally implausible now but conceivable in the future - would be to create a mechanism that requires payments of dividends when certain benchmarks are met by a firm. Proposals for minimum dividend payments have been floated in the American context, but could prove even more useful in the Russian one. Most importantly, minimum dividend payments by firms with a certain level of assets or revenues, could help people come to view shares as financial instruments, rather than just as levers for control.

\section{CONCLUSION}

A typology of Russian corporate governance can offer useful

Id. 
lessons for corporate governance theory. The rich array of deviant behavior we canvass in Russia helps flesh out a framework of pathologies that, in a comprehensive way, links corporate governance failures to real economy effects. How is this analytic tool useful? It helps give more precision to the often vague notion of corporate governance failures. Scholars write about the costs of poor corporate governance without telling us the mechanisms by which loosely constrained and poorly incentivized managers are causing social welfare losses. We suggest that in every economy, those losses may be inflicted in differing degrees through five distinct pathologies of non maximization of residuals and two versions of non pro-rata distributions. Identifying which pathology predominates may help point to more appropriate corporate governance reforms.

The second focus of the paper - explaining what has caused the flowering of Russian corporate pathologies - may also prove useful for corporate governance theory. Not surprisingly, the existing scholarly literature on comparative corporate governance mostly reflects the experience of United States, Western Europe and Japan. In the United States, it is unusual for a corporation to maintain a share ownership pattern over the long term that involves a majority of shares owned by insiders and a minority owned by outsiders who trade their shares publicly. Our understanding of the mechanisms that constrain management to act in relatively share-value-maximizing ways - one share, one vote, the hostile takeover threat, share price based management compensation schemes, board elections, shareholder approval of certain interested and extraordinary transactions, ex post court review, the managerial labor market and other reputational incentives - is built primarily against the U.S. backdrop because the typical American corporation forms the paradigm for theorizing.

We suggest that looking at Russia introduces an analytic focus not immediately obvious from studying such long-established systems. Among other things, we see concretely that initial conditions matter for subsequent corporate governance development. The Russian experience suggests two salient initial conditions, uneconomic firm boundaries and competing groups of insider owners, that offer avenues for further research. At a minimum, the bargaining failures that followed privatization provide evidence that counsels skepticism towards the periodic claims of some scholars and activists for including "stakeholders" - such as labor, the local community and the local government itself - in corporate governance. The Russian experience reminds us, also quite starkly, of the tradeoff between the agency costs of 
management in a publicly held corporation and the disadvantages of lack of access to public equity finance. This tradeoff appears in the leveraged buyouts of the late 1980s and the "going private" trend of the early 1970s: firms involved in both movements have tended to go public again at some later point.

More generally, the Russian experience suggests we rethink how close corporations operate. While there is a well-developed jurisprudence of close corporations in the United States, there is only a modest literature on the economics of such legal relations. Governance of the close corporation has traditionally been viewed by lawyereconomists as a contracting problem among well-informed, wellrepresented, motivated individuals, where the best policy advice that can be given is to have the law not obstruct the deals these individuals might reach.

The bargaining failures that followed privatization in Russia could shed light on our own system by focusing attention on the understudied area of losses from fragmented ownership in close corporations and other special corporate governance arrangements such as those associated with start-up companies backed by venture capital. When insiders exercise their rights so that each blocks the others, corporate assets may be wasted in a "tragedy of the anticommons." 141 If competing blocks of insiders have incentives each to veto share value-maximizing decisions, or if the costs of aggregating and negotiating insider interests to reach such decisions are sufficiently high, then corporate assets may be wasted in low value uses. In short, the Russian experience counters recent theoretical and empirical research which argues that control by multiple large shareholders actually improves firm performance. ${ }^{142}$

The Russian experience of corporate governance is unique; nowhere else in the world offers such creative and ample corporate governance pathologies, nowhere else do firms have such strange boundaries and competing insiders so much control. But the lessons that Russia teaches are not parochial at all. Russia's enterprise pathologies improve our basic understanding of how corporate governance works.

141 See Heller, supra note *, at 621-26.

142 David L. Kang, The Internal Control of Organizations: How Large-Block Ownership by Insiders Leads to Increased Firm Performance (1997) (mimeo on file with authors); Armando Gomes \& Walter Novaes, Multiple Large Shareholders in Corporate Governance (1999) (mimeo on file with authors). 